Article

\title{
Agricultural Land or Photovoltaic Parks? The Water-Energy- Food Nexus and Land Development Perspectives in the Thessaly Plain, Greece
}

\author{
G.-Fivos Sargentis *(D), Paraskevi Siamparina, Georgia-Konstantina Sakki, Andreas Efstratiadis (D), \\ Michalis Chiotinis and Demetris Koutsoyiannis
}

Laboratory of Hydrology and Water Resources Development, School of Civil Engineering, National Technical University of Athens, Heroon Polytechneiou 9, 15780 Zographou, Greece; cv14038@mail.ntua.gr (P.S.); sakkigk@mail.ntua.gr (G.-K.S.); andreas@itia.ntua.gr (A.E.); mchiotinis@mail.ntua.gr (M.C.); dk@itia.ntua.gr (D.K.)

* Correspondence: fivos@itia.ntua.gr

Citation: Sargentis, G.-F.; Siamparina, P.; Sakki, G.-K.; Efstratiadis, A.; Chiotinis, M.; Koutsoyiannis, D. Agricultural Land or Photovoltaic Parks? The Water-Energy-Food Nexus and Land Development Perspectives in the Thessaly Plain, Greece. Sustainability 2021, 13, 8935. https://doi.org/ $10.3390 /$ su13168935

Academic Editors:

Kittisak Jermsittiparsert,

Thanaporn Sriyakul and

Muhammad Haseeb

Received: 29 June 2021

Accepted: 6 August 2021

Published: 11 August 2021

Publisher's Note: MDPI stays neutral with regard to jurisdictional claims in published maps and institutional affiliations.

Copyright: (c) 2021 by the authors. Licensee MDPI, Basel, Switzerland This article is an open access article distributed under the terms and conditions of the Creative Commons Attribution (CC BY) license (https:/ creativecommons.org/licenses/by/ $4.0 /)$.

\begin{abstract}
Water, energy, land, and food are vital elements with multiple interactions. In this context, the concept of a water-energy-food (WEF) nexus was manifested as a natural resource management approach, aiming at promoting sustainable development at the international, national, or local level and eliminating the negative effects that result from the use of each of the four resources against the other three. At the same time, the transition to green energy through the application of renewable energy technologies is changing and perplexing the relationships between the constituent elements of the nexus, introducing new conflicts, particularly related to land use for energy production vs. food. Specifically, one of the most widespread "green" technologies is photovoltaic (PV) solar energy, now being the third foremost renewable energy source in terms of global installed capacity. However, the growing development of PV systems results in ever expanding occupation of agricultural lands, which are most advantageous for siting PV parks. Using as study area the Thessaly Plain, the largest agricultural area in Greece, we investigate the relationship between photovoltaic power plant development and food production in an attempt to reveal both their conflicts and their synergies.
\end{abstract}

Keywords: water-food-energy nexus; photovoltaic park; land use; sustainable development; humanitarian crisis

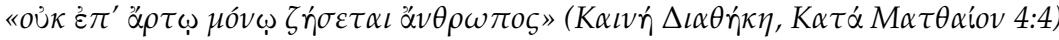

"Man shall not live on bread alone" (New Testament, Matthew 4:4)

\section{Introduction}

Humans need a constant supply of water, food, and energy to live. These resources are connected to life expectancy, prosperity, and wealth [1], and are necessary in sufficient quantity and quality. The survival limits of humans are seven days at most without water, and about 45 days without food [2], which also represents the energy source for the human body. Thus, food and water require constant replenishment. As energy is essential for prosperity [1], the whole structure of society has been diachronically shaped and has evolved through systematic expansion of its energy consumption.

The multiple and complex interconnections between water, energy, and food, either expressed as complementarities or conflicts, raised the need for an integrated viewpoint, to ensure a fair and sustainable sharing of the three vital resources across all scales of interest (international, national, local). In this vein, the concept of the water-energy-food (WEF) nexus is recognized as the running paradigm for their combined planning and management [3-7].

In addition to these three critical elements, land is also a precious resource [8-10]. Land is needed for food production or for cultivating biofuels, both raising water needs for irrigation [11-14]. Recently, it has also been used for the installation of all kinds 
of infrastructures that are associated with energy and water production [15]. In this vein, a major conflict arises within the WEF nexus, given that land is their common interface [16-18].

One of the most important aspects of the global shift towards sustainability is the transition to renewable energy (RE) technologies. The shift to renewables introduces further challenges within the WEF nexus. A characteristic example is the worldwide expansion of photovoltaic (PV) energy, also emerging from the attractive financial opportunities offered, which has resulted in an expanding occupation of agricultural land, since the latter offers significant advantages for installing PV panels. Hence, the motivation of this research is the growing concern over the degradation of agricultural and livestock production as a result of the occupation of agricultural land for the establishment of PV power stations. For this reason, an attempt is made here to investigate the competitive relationship between PV power plants and food production. As a case study, we consider the area of Thessaly, which is one of the key areas for the primary sector in Greece and the biggest agricultural area in Greece. The vast expanse of flatland, in combination with the abundance of solar resource, favors the development of PV systems, attracting a large number of investors. Our analyses aim at the assessment of transforming the plain from a food production area to an energy production area.

\section{Energy Flow: From Sun to Humans}

The Sun and Earth are the sources of WEF nexus which are precious goods. Koutsoyiannis [19] notes that:

The total energy involved in the hydrological cycle is $1.290 \times 1024 \mathrm{~J} \mathrm{yr}^{-1}$ or $1290 \mathrm{ZJ}$ $\mathrm{yr}^{-1}$. This is about half the global solar energy absorbed by the Earth (161 W m $\mathrm{m}^{-2}$, according to Trenberth et al. 2009 [20]). Compared to the human energy production, which in the past decade was about 170,000 TWh $\mathrm{yr}^{-1}$ or $0.612 \mathrm{ZJ}^{-1} \mathrm{r}^{-1}$ (corresponding to the year 2014; Mamassis et al. 2021 [21]), the total energy involved in the water cycle is 2100 times higher. Put differently, the total human energy production in 1 year equals the energy consumed (or released) by the hydrological cycle in about $4 \mathrm{~h}$.

Summarizing, we conclude that half of the energy provided by the Sun is being consumed in the water cycle, and its consumption is a necessary condition for human life [22]. A small part of the other half is being used to convert inorganic matter to organic matter [23]. Humans consume a small part of the organic matter as food (animals, plants) and another part as energy (wood, oil [24], etc.), which is essential for prosperity (Figure 1).
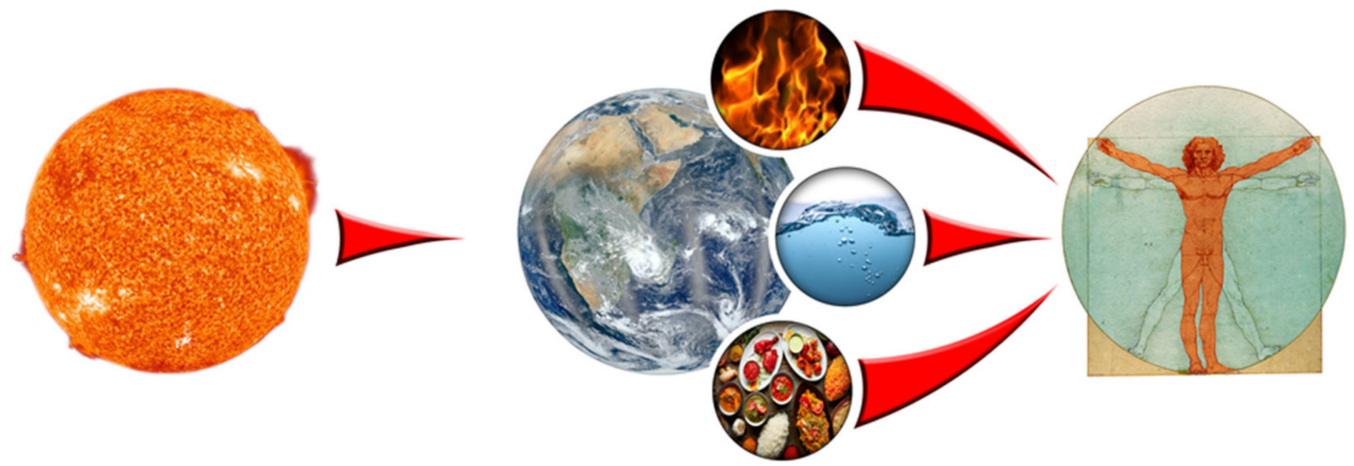

Figure 1. Solar energy moves the water circle and transforms inorganic matter into useful organic. Water, food, and energy supplies are essential for human survival and prosperity.

\section{The Competition between WEF}

An important issue is to detect and describe the interactions within the WEF nexus. We will explore the interaction in clockwise direction (Figure 2a) and counter-clockwise direction (Figure 2b). 


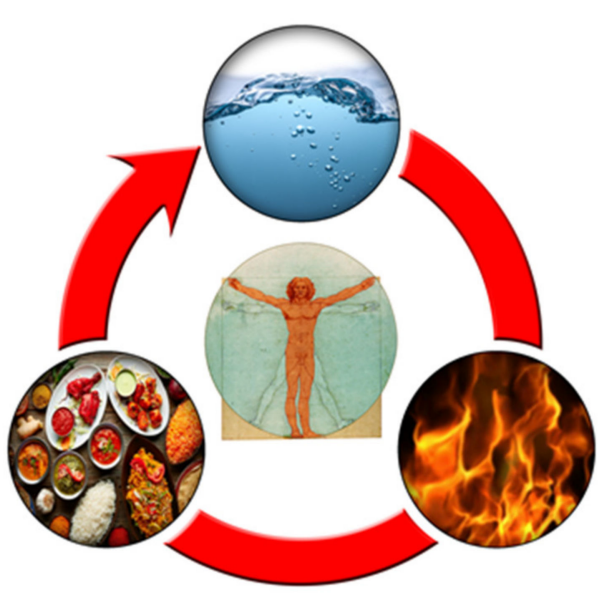

(a)

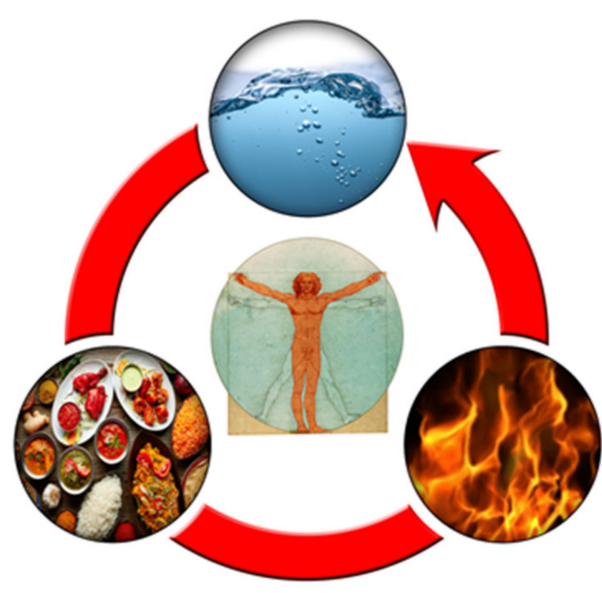

(b)

Figure 2. The interaction between water-food-energy nexus. (a) clockwise direction; (b) counterclockwise direction.

\subsection{Clockwise Direction}

\subsubsection{Water to Energy}

- There are several water and energy interactions [25].

- Hydroelectric energy can only be generated if water is readily available in rivers or reservoirs [26,27].

- While hydroelectric energy does not consume water, the cultivation of plants for biofuel [28-31] consumes significant amounts of water, so we note a hidden cost of water in this process $[32,33]$.

\subsubsection{Energy to Food}

- Solar energy is a basic requirement for the cultivation of plants. The production of food is an energy expensive process. Food production consumes globally $30 \%$ of total energy [26] (harvesting, tillage, processing, storage).

- The production of fertilizers is an energy intensive process.

\subsubsection{Food to Water}

- Water is incorporated within the produced food.

- Fertilizers have a negative effect on the quality of water and have serious implications for ecosystems.

\subsection{Counterclockwise Direction}

\subsubsection{Water to Food}

- Yields of irrigated agricultural land are higher.

\subsubsection{Food to Energy}

- By consuming food, we provide energy for our organs to function [34]. Interestingly, the human brain consumes $\sim 20 \%$ of the body's energy (350 or 450 calories per day), despite making up only $\sim 2 \%$ of the body's mass [35,36].

- Biofuels are produced by food (e.g., corn, soya).

- Land is used for mining, cultivation of biofuel plants, and PV panels, creating competition to the cultivation of food.

\subsubsection{Energy to Water}

- Groundwater (which needs energy to be pumped in order to be useful) is the world's most extracted natural source. Koutsoyiannis estimates groundwater uses from several 
studies, based on global hydrological models and GRACE data, to be $300 \mathrm{~km}^{3} /$ year in recent years [19].

- Natural water, clean water, and wastewater need energy for treatment and transportation.

- Water distribution and especially desalination are energy intensive processes.

\subsection{Land Use Related to Food, Energy, and Water}

- It is important to highlight the competitive relationship of land uses with the waterfood-energy nexus. Land can be used:

- For food production

- For energy production cultivation of biofuel plants, installation of PV panels, and creation of reservoirs in hydroelectric dams.

Biofuel plants use land and water to produce energy instead of food. PV panels use land to produce energy without water. Using the land for reservoirs, hydroelectric projects produce energy using water.

\section{The Role of WEF for Humans}

Clarifying the role of WEF nexus for humans, this paper begins correlating life expectancy with the availability of three elements.

\subsection{Water}

Water is a key component of living. Although safe drinking water technologies have improved in recent decades, 2.2 billion people worldwide still do not have access to safe drinking water, and more than half of the world's population has no access to safe sewage [37]. Globally, approximately $70 \%$ of freshwater withdrawals are irrigating agriculture areas [38] and $20 \%$ are used for industrial purposes [39].

Urbanization and high living standards increase the water withdrawal worldwide over the last 100 years [40,41]. As the population is growing just as fast, water withdrawal per capita appears to remain constant (Figure 3a). In a country's average data, water withdrawal per capita is not related to life expectancy, as the data show much scatter (Figure $3 b$ ). This is justified considering natural factors, such as the climate and economic profile of each country [21,42] (Figure 4).

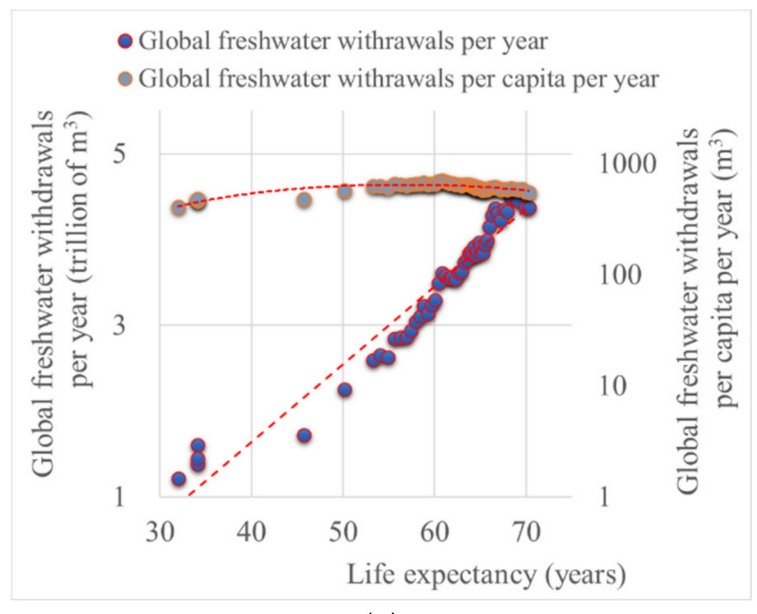

(a)

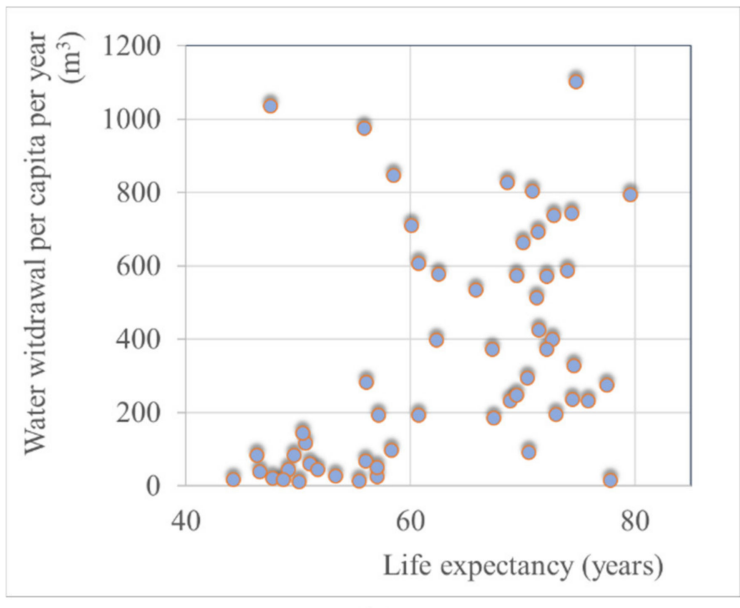

(b)

Figure 3. Life expectancy related to freshwater withdrawal: (a) global average through 1870-2011; (b) average per country in 2000 [43-48]. 


\section{Life expectancy (years) $45 \quad 82$}

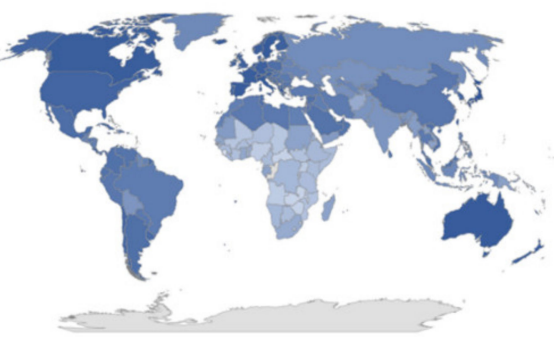

GDP per capita $\quad 450 \quad 70,000$ per year (2011 USD)
Water withrawal $\quad 0 \quad 1100$ per capita per year $\left(\mathrm{m}^{3}\right)$

Figure 4. Global spatial data, average per country (2000). Life expectancy, GDP, per capita, and water withdrawal [43-48].

\subsection{Energy}

Energy is the global currency as it is strongly correlated with prosperity (life expectancy and GDP per capita). Wilhelm Ostwald was the first to highlight the correlation between energy consumption and life expectancy, in 1909 [49]. The data in Figure 5 verify it.

There is a large inequality of per capita energy use between countries. In countries with high GDP, the largest share of energy is used for transport and heating. In countries with low GDP, cooking has the highest share in energy consumption (Figure 6) [50].

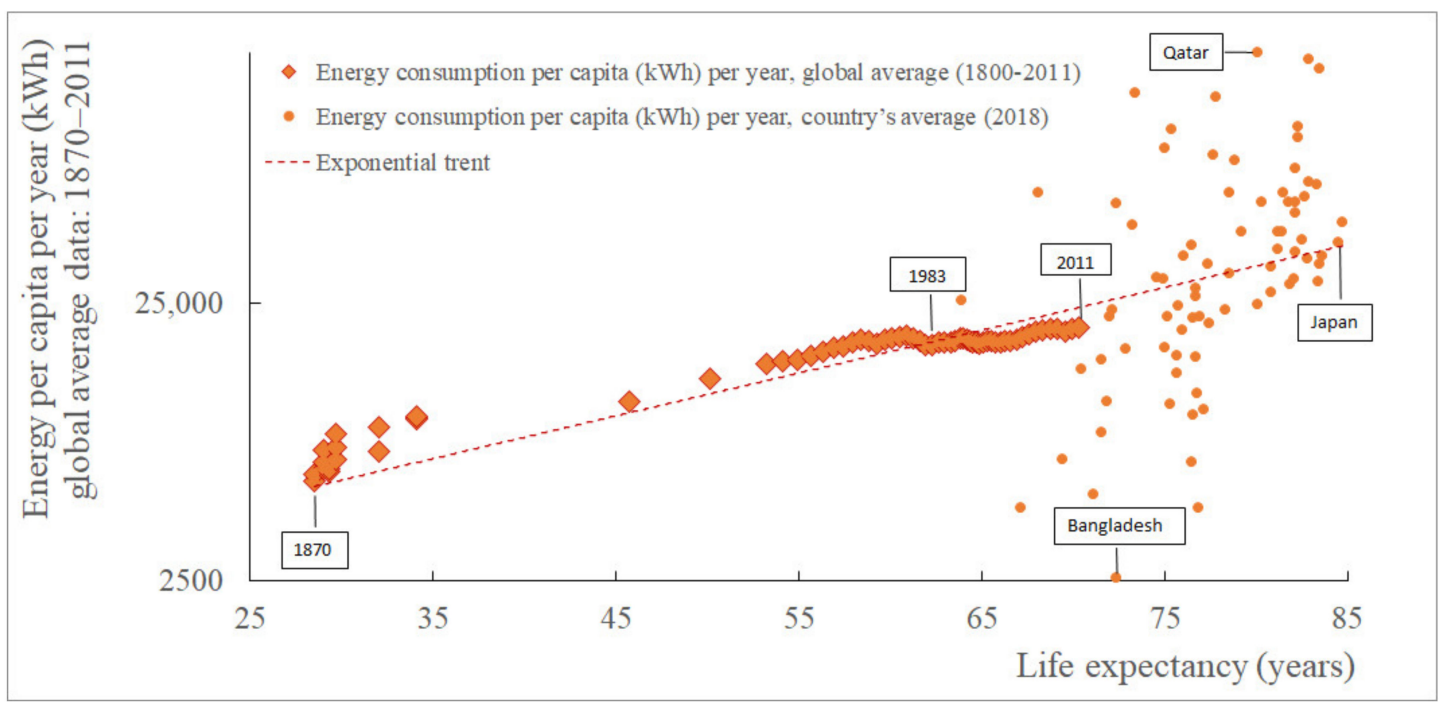

Figure 5. Global spatial data, average per country (2010). Life expectancy, GDP, per capita and energy consumption per capita per year $[47,48,51,52]$.

Life expectancy (years) $5 \overline{5} 85$

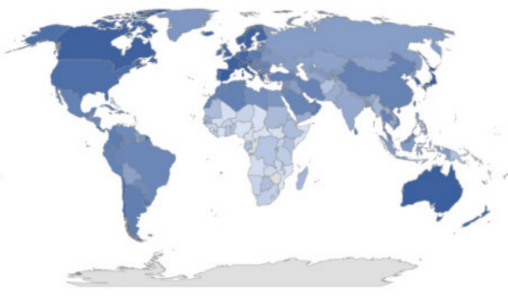

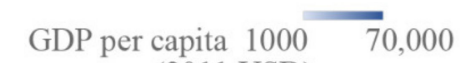
per year (2011 USD)

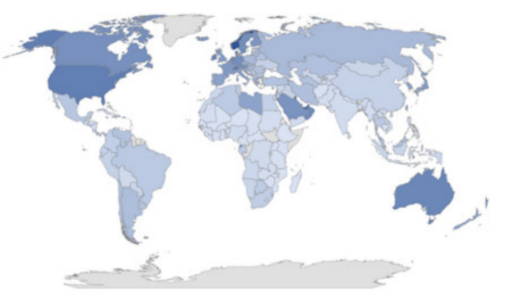

Energy consumption $(\mathrm{kWh}) \quad 0 \quad 100,000$ per capita per year $\left(\mathrm{m}^{3}\right)$

Figure 6. Life expectancy related to per capita consumption of energy per year; global average, data from: 1870-2011; country's average, data from: $2018[47,51]$. 


\subsection{Food}

Food is a commodity derived from plants and animals. Human diet provides nutrients such as carbohydrates, fats, fibers, protein, vitamins, and minerals. These and other chemical compounds are essential for basic bodily function.

Food production began with small farms and animal husbandry. Population growth and urbanization caused significant changes to agricultural production with new, optimized farming methods. As modern agriculture needed less workers, it favored the influx of population into cities.

Food is now based on primary production (agriculture) and secondary (industrial food processing). Production and consumption are connected through supply chains, trade, markets, prices, and price volatility. There are several problems with food management: 1.6 billion tons every year are wasted (1.3 billion tons are edible) [53] but many people do not have access to food in developing countries [54-56].

Food is closely correlated with life expectancy (Figures 7 and 8). It is obvious that living prosperously is associated with higher caloric supply, following the same pattern of life expectancy and GPD per capita.

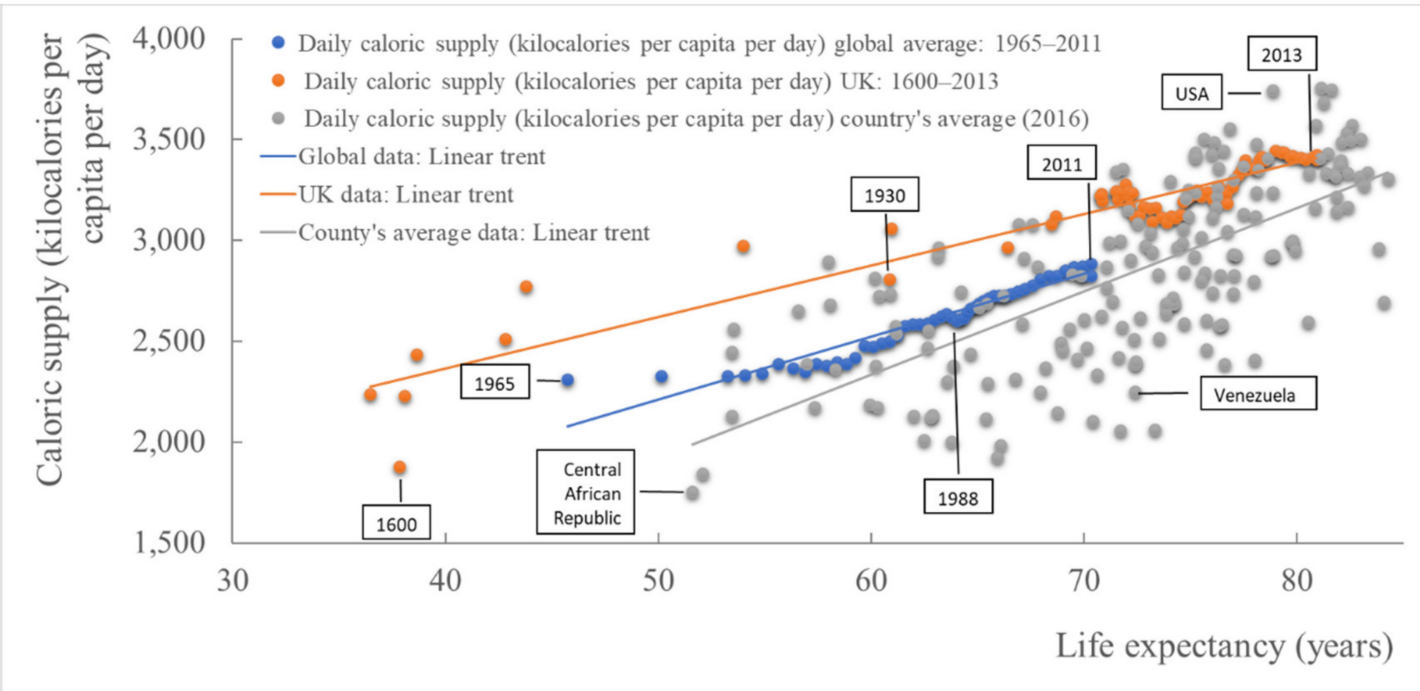

Figure 7. Life expectancy related to daily caloric supply; global average (1965-2011) and county's average data (2016) [47,57]; UK data (1600-2013) [58].

Life expectancy (years) $55 \quad 85$

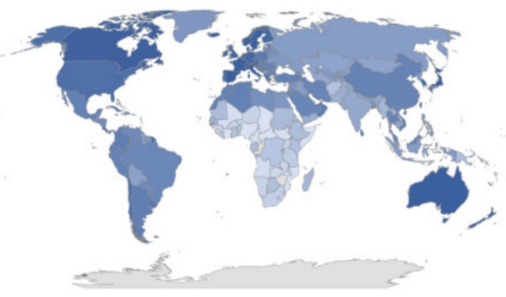

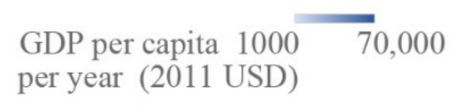

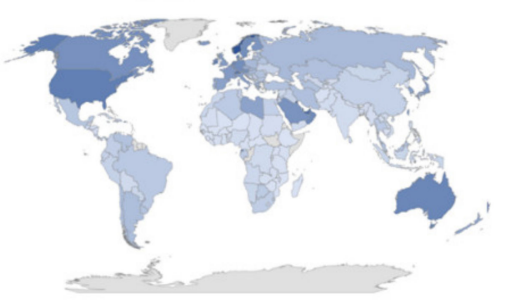

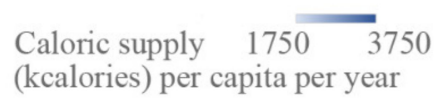

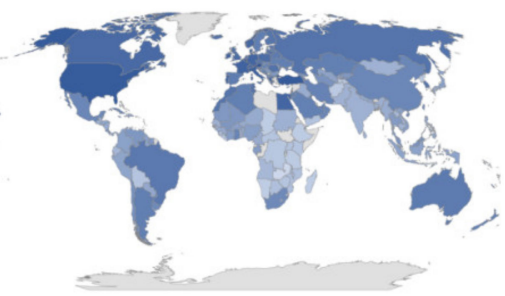

Figure 8. Global spatial data, average per country (2010). Life expectancy, GDP, per capita, and caloric supply per capita per year $[47,48,57]$.

\section{Overview of WEF, Land Synergies, and Conflicts}

\subsection{Studding the WEF Nexus}

References to "water, energy, food" in papers and articles can be found starting in the 1960s (Figure 9). In 2009, Koutsoyiannis et al. [59] connected the competition of these issues and the necessity to study them together under the prism of uncertainty. 
The nexus's potential has been clear among the scientific community since $2011[53,60]$ (Figures 10 and 11) and in recent years, the WEF nexus has been of particular interest to the scientific community [61-64]. Furthermore, there are many attempts at the transition from the theoretical aspects of WEF nexus to the practical ones [65].

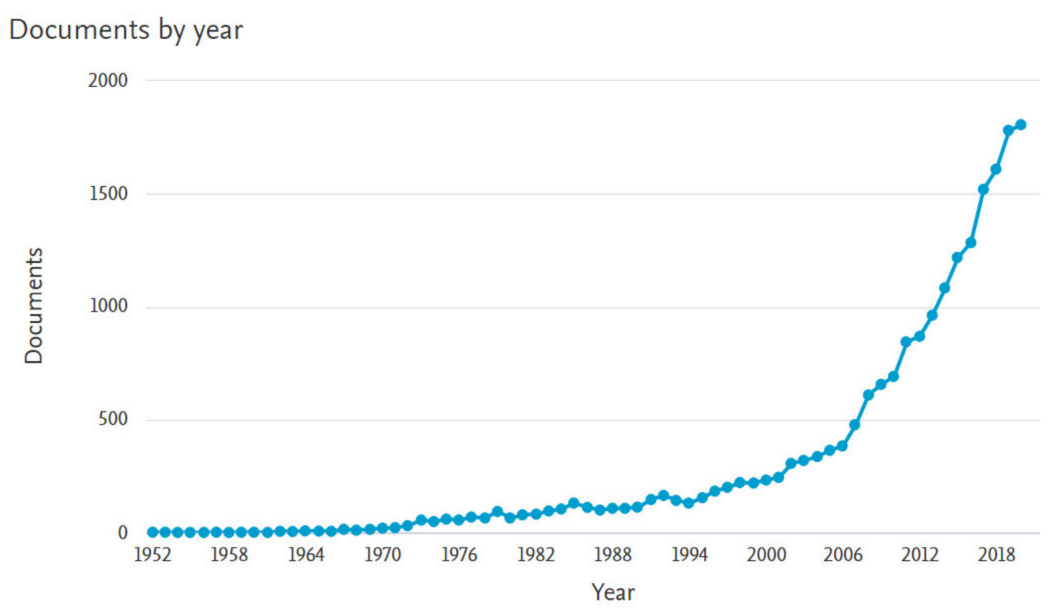

Figure 9. Evolution of the frequency of appearance in the 78 million items contained in the Scopus database of scientific articles (the search was conducted over "all fields") until 2020 of the term "water food energy".

Documents by year

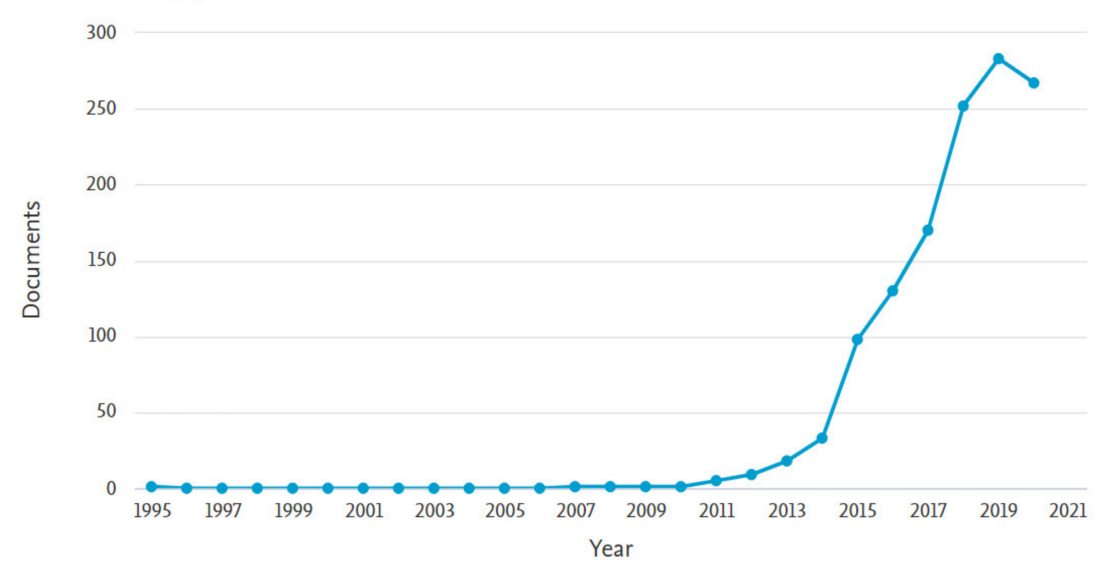

Figure 10. Evolution of the frequency of appearance in the 78 million items contained in the Scopus database of scientific articles (the search was conducted over "all fields") until 2020 of the term "water energy food nexus".

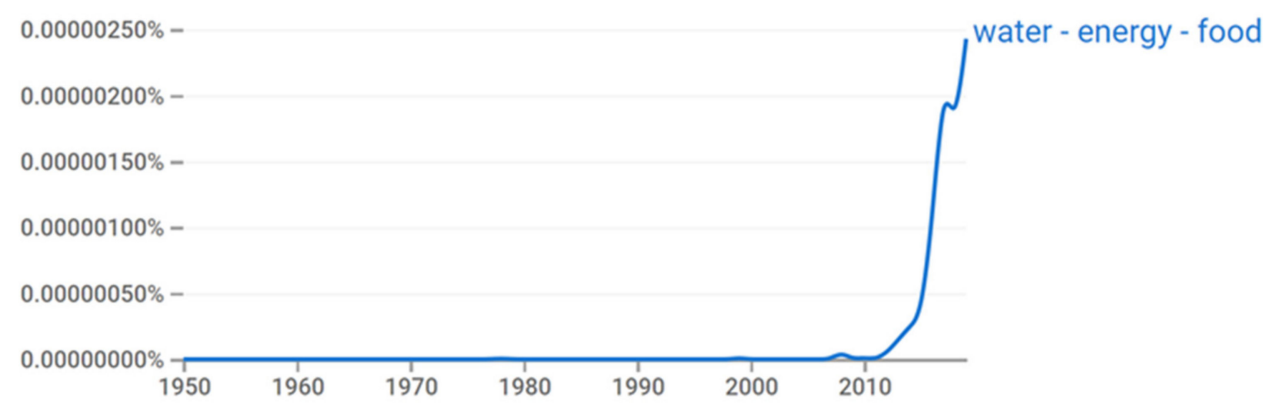

Figure 11. Evolution of the frequency of appearance of the term "water-energy-food" in the millions of books archived by Google Books. 


\subsection{Society, Water-Food-Energy Nexus, and Optimization Aspects}

In prehistory, humans relied on energy and water to transition from hunter-gatherers to farmers, and this gave them the ability to cluster in smaller spaces like cities [1] and the increase of clustering gives rise to civilization [66]. Today, humanity is facing a major challenge: the rapidly growing demand for WEF. Population growth, the different ways of life of each society, and the urgent need to improve WEF security for the poorest are putting increasing pressure on resources [67]. Unless there are significant changes in production and consumption patterns, agricultural production should increase by about $60 \%$ until 2050 and global electricity production is projected to increase by about $60 \%$ over the next ten years $[68,69]$. Thus, we note that a careful management of the nexus is required.

Throughout history, there was inequality in the distribution of resources. At present, in order to show the inequality of distribution, we use the entropic index of inequality [1] $\Delta \Phi$ : for energy: 0.92 ; for food: -0.51 . Note that $\Phi$ denotes the entropy and $\Delta \Phi$ is the difference of the entropy of the particular distribution of income from the entropy of the exponential distribution with equal mean value. As $\Delta \Phi$ approaches 0 or becomes negative the equality increases and as $\Delta \Phi$ approaches 1 , inequality is maximized.

Figure 12a,b show the plots of exceedance probability related to energy consumption and daily caloric supply in different countries for the year 2010. Data show a wide range of inequality in energy use. In contrast, as nutrition needs have small range in caloric supply, the inequality in caloric supply is faint.

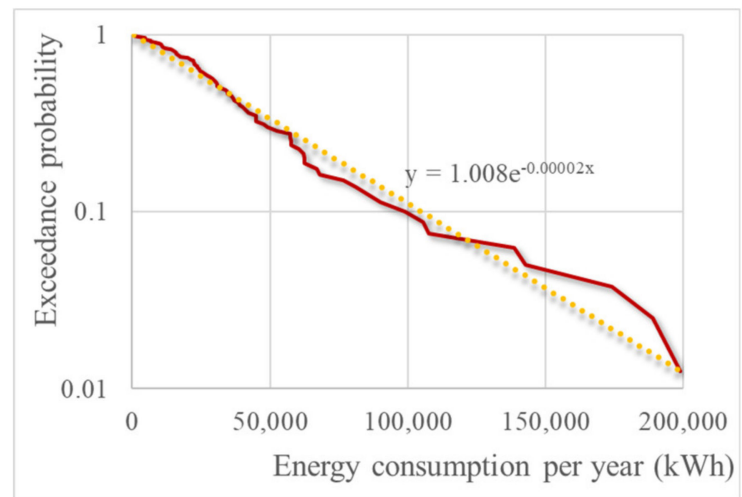

(a)

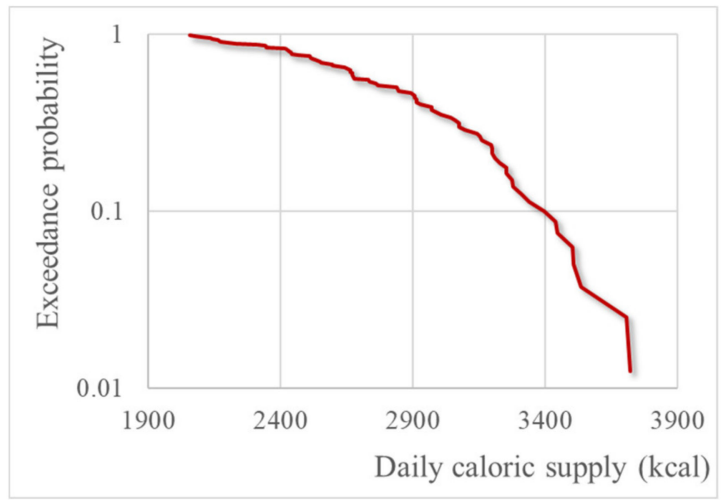

(b)

Figure 12. Country's average (2010): exceedance of probability of (a) energy consumption (b) daily caloric supply [51,57].

Notably, the optimization of WEF nexus management is already part of the evolution process of Homo sapiens. Related papers have given an overview of the relationship, through the evolution process, of Homo sapiens with items such as:

- water and food consumption [66],

- walking on two feet which was an energy-saving step [70], and

- $\quad$ the function of the brain, which is more energy efficient than in animals [71].

As the WEF nexus is so critical for human survival, and the abundance of resources is connected to life expectancy (Figures 3-8), an optimization of WEF nexus management is required. In this aspect, the target should be to isolate the individual parts of the nexus and minimize the associated conflicts, e.g., water for food, water for energy, energy for water, energy for food, fertilizers for food, etc.

In these circumstances, an important issue is to ensure secure access to the WEF nexus for all people, reducing inequalities.

\subsection{PV Development in Agricultural Lands}

Since the beginning of the 21st century, the penetration of RE sources has been growing rapidly, and their share in the electricity mix is expected to further increase. Despite the 
large advantages of RE over conventional fossil fuels, there is a growing concern over the globe that large-scale RE infrastructures will displace other land uses, thus resulting in severe socio-economic and environmental impacts and irreversible alterations to landscapes [72-75].

After hydroelectric and wind energy, PV energy is the third most important form of RE worldwide. Global PV capacity has substantially grown from around 5 GW in 2005 to $714 \mathrm{GW}$ in 2020 [76]. This expansion is explained by the rapid fall in costs for solar PV, on the one hand, and the financial and legislative motivations provided at the national and international level (e.g., the EU), on the other. In this context, one of the most typical conflicts among RE and land resources involves the development of PV solar plants in rural areas, and particularly over agricultural lands.

There are multiple reasons making agricultural lands so attractive for the deployment of PV systems on a large scale. It is well known that the electrical power of solar PVs is a conversion of the incoming solar radiation, direct and diffuse, which depends on the geographic location and strongly influenced by the local topography [77]. On the other hand, the efficiency of PV panels, although primarily dependent on the technical characteristics of the specific system (silicon type, cell layout and configuration, panel size, color of protective backsheet, etc.), is also significantly affected by the local microclimate, mainly the temperature. It is recognized that the most suitable land conditions for maximizing PV potential are croplands, grasslands, and wetlands, which are characterized by plentiful insolation, light winds, moderate temperatures, and low humidity [78]. Apparently, croplands are more suitable since they combine a relatively low cost for land reservation, easy accessibility to the road and electrical grid network, and minimal interventions for the preparation of the installation terrain (e.g., grading). Hence, they are strongly preferred by investors seeking plain areas with such beneficial characteristics to deploy large-scale solar parks (indicatively, a solar park of $1 \mathrm{MW}$ capacity needs a development area of about 2.6 ha). On the other hand, an increasing number of landowners and farmers find more gainfulness to grant their lands to energy investors, in order to ensure a steady and low-risk income, which may exceed their net profit from agricultural production.

Under this premise, from the beginning of RE expansion, there is a long-standing discussion on the impacts of capturing agricultural land for the installation of large-scale PV systems [79-81]. Apart from the obvious question, i.e., whether it is possible to fulfill the needs for food and energy under limited land resources [82,83], PVs in agricultural areas are also associated with environmental degradation, including landscape deterioration [84,85], land take, soil degradation, and loss in traditional cropland and biodiversity [86].

However, recent advances under the water-energy-land-food nexus approach have brought to light innovative solutions for overcoming the conflicts between energy and land uses and co-developing the same land area for both solar PV power and conventional agriculture. In this respect, there is a global interest in the so-called agrophotovoltaic or agrivoltaic systems [87-89], which are suitable for shade-tolerant crops and they also offer quite significant advantages with respect to PV efficiency. The experience reported so far is quite encouraging. Nevertheless, it is generally accepted that such synergetic schemes are economically effective under specific climatic conditions (i.e., arid or semi-arid) and for locations with intense competition for land resources, e.g., islands [90].

\section{Case Study: The Camp of Thessaly}

\subsection{Overview of the Food-Land-Energy Nexus in Thessaly}

The district of Thessaly extends over an area of 1,403,600 ha in central Greece, where 403,045 ha is the cultivated land (Figure 13), thus covering over $10 \%$ of the country's agricultural land [91,92]. The extensive agricultural production in the plain of Thessaly is facilitated by the topography and the fertile land resources. 


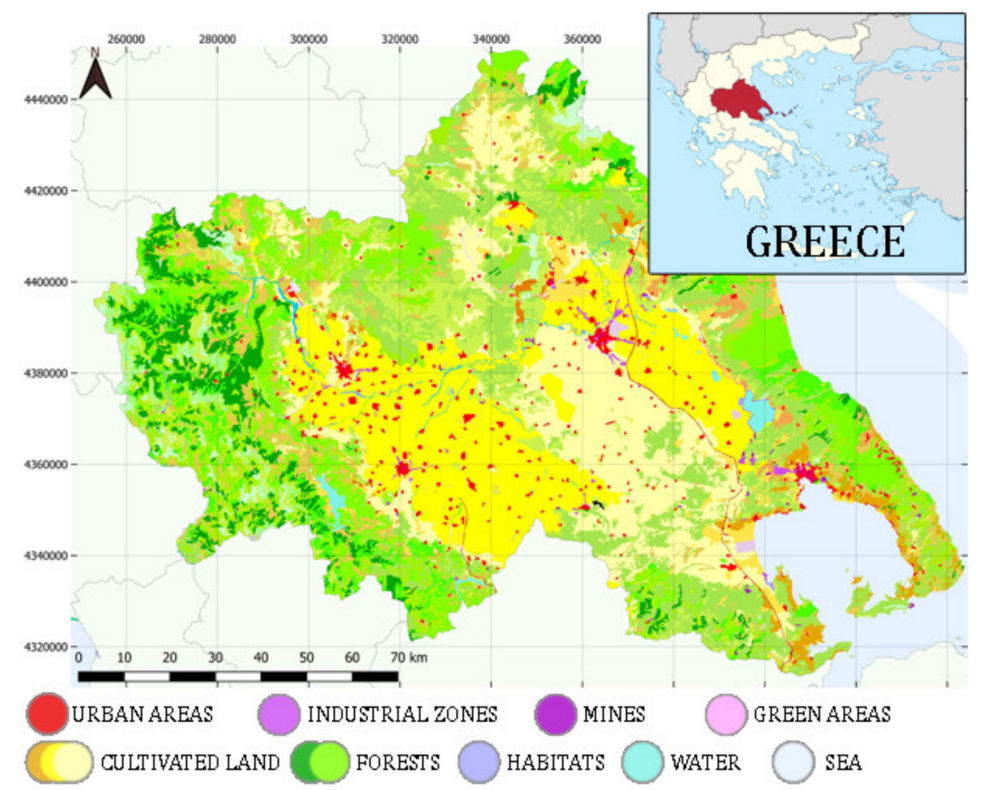

Figure 13. Land use of Thessaly (Corine Land Cover 2018) [93].

Forty percent of cultivated land is irrigated, which puts pressure on both surface and groundwater resources, since irrigation of crops is the largest consumer of water (Table 1). The estimated annual water intake for all uses is $1422 \mathrm{hm}^{3}$ and $24 \%$ concerns surface water, while $76 \%$ comes from drilling groundwater $[94,95]$. The annual deficit of groundwater is $474 \mathrm{hm}^{3}$ and is caused by the intensive and unsustainable use mostly of groundwater.

Table 1. Water consumption in Thessaly.

\begin{tabular}{cc}
\hline Type of Consumption & Water Quantity $\mathbf{( h m}^{\mathbf{3}} \mathbf{)}$ \\
\hline Irrigation (2013) & 1306 \\
Municipal water & 94 \\
Livestock & 13 \\
Industry & 9 \\
Total & 1422 \\
\hline
\end{tabular}

The annual crops are fully mechanized in all production stages from sowing to harvest. As an order of magnitude, modern farming consumes $25 \mathrm{GJ} / \mathrm{ha} / \mathrm{y}$ [96-107], thus resulting in the annual energy needs for cultivation being about 8 million GJ (or 2.8 TWh). For comparison, the total annual energy consumption in Greece in 2019 was about 319 TWh, of which 48 TWh was the electric energy demand [108].

In recent years, the interest of investors in Greece has been focused on RE, also raised by significant financial incentives provided by national and the EU legislation. The installation of renewables in Greece is controlled by the Regulatory Authority for Energy (RAE). RAE is an independent authority established by Law 2773/1999 [109], which harmonized the Greek legal order with EU Directive 96/92/EC [110] and is empowered to monitor the operation of all sectors of the energy market.

After wind energy, solar energy, mainly by means of PV parks, is the mostly developed source of renewable energy in Greece. It is remarkable that the sharing of solar energy to the electricity mix of the country increased from less than $0.3 \%$ to $9.0 \%$, in the last decade. In particular, the Thessalian plain is strongly beneficial for installing PV panels, since it is a vast flat land, receiving an average annual solar energy of 1440 to $1590 \mathrm{kWh} / \mathrm{m}^{2}$ [111]. Figures 14 and 15 show the land uses over Thessaly, also highlighting the licensed solar parks exceeding $1 \mathrm{MW}$ [112]. 


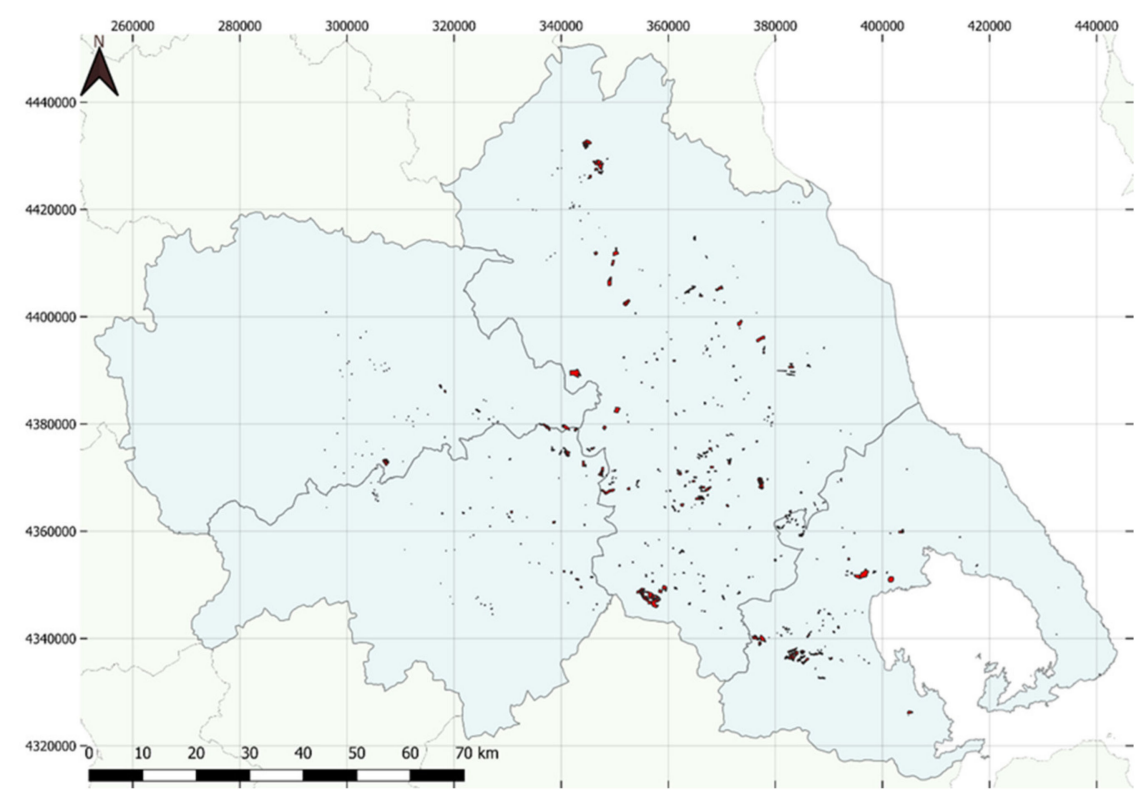

Figure 14. PV panels larger than $1 \mathrm{MW}$ in Thessaly's cultivated land [112].

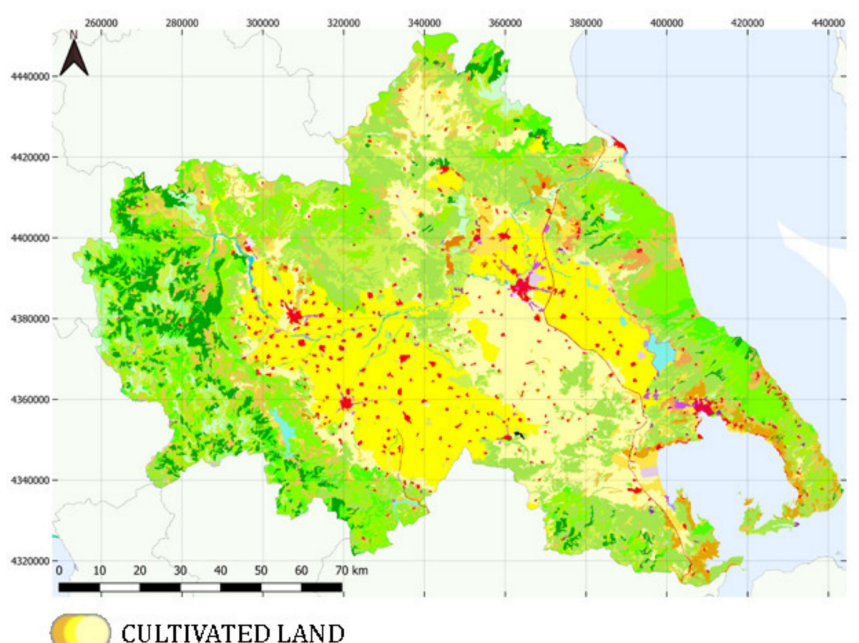

(a)

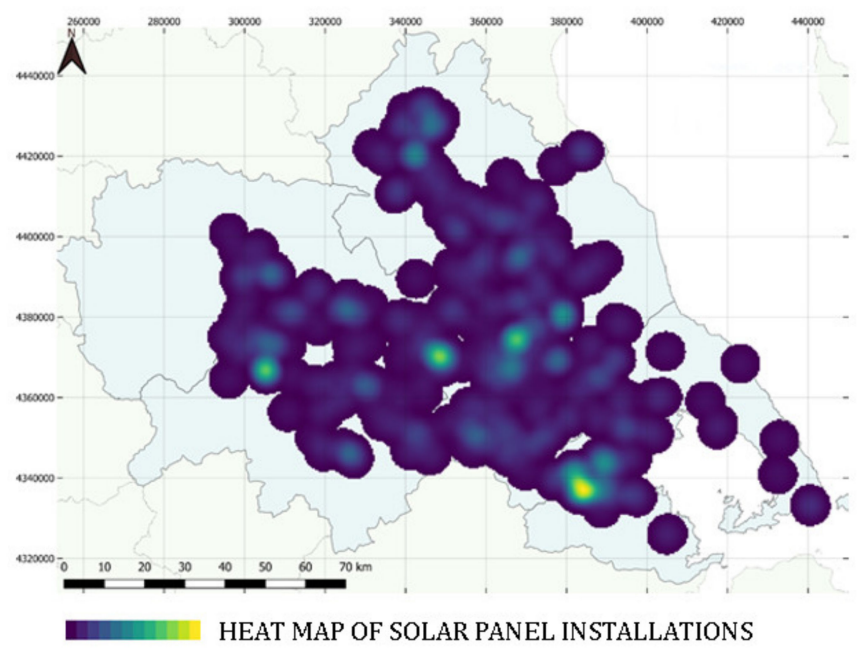

(b)

Figure 15. (a) Land use of Thessaly; (b) heat map of the installation of PV panels lager than 1 MW in Thessaly's cultivated land.

According to a recent Greek law (valid from March 2020) [113], the maximum allowable solar power capacity in agricultural land of Thessaly is $2758 \mathrm{MW}$. The solar capacity so far is $1711.5 \mathrm{MW}$, while the licensed parks cover $\sim 1 \%$ of cultivated land. Based on approximate data from the Global Solar Atlas [114], we estimate that the current solar energy production in Thessaly is $1485 \mathrm{kWh} / \mathrm{kWp}$. This means that currently, Thessaly produces about 9 million GJ (about $2.5 \mathrm{TWh}$ ). Assuming that all potential solar capacity allowed by the law is installed, the produced annual energy will be approximately 15 million GJ (4.2 TWh), which exceeds the energy needs for food production in the entire area of Thessaly.

\subsection{Quantitative Analysis}

In order to evaluate the conflicts and possible synergies between the three resources of interest, i.e., food, land, and solar energy, we employed an economic comparison of PV panels development vs. agricultural activity, having as "common denominator" the 
associated occupied area [115]. As a proof of concept, we considered two alternative cultivations, namely wheat, which is the traditional agricultural product of Thessaly, and kiwifruit. The latter is native to the Yangtze Valley of northern China and Zhejiang Province on the coast of eastern China [116]. Currently, the main region of kiwifruit cultivation in China is the central and lower Yangtze River Valley.

Climatic data shows that kiwifruit native land has the same range of temperatures with Thessaly (Figure 16a) but totally different characteristics of rainfall (Figure 16b). Specifically, the annual average rainfall in Thessaly is about $500 \mathrm{~mm}$ [94] and the average of three different areas in Yangtze river valley is about $1600 \mathrm{~mm}$. In order to optimize the kiwifruit production and adjust cultivated land of Thessaly's plain, to the environmental conditions of Yangtze river valley, farmers need $7000-8000 \mathrm{~m}^{3}$ of water per hectare for irrigation $[117,118]$. On the other hand, the water needs of wheat are much more limited and they do not exceed $1500 \mathrm{~m}^{3} / \mathrm{ha}$.

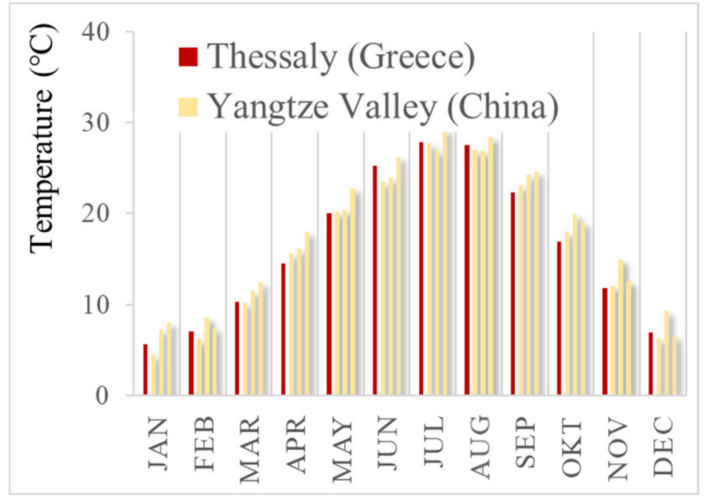

(a)

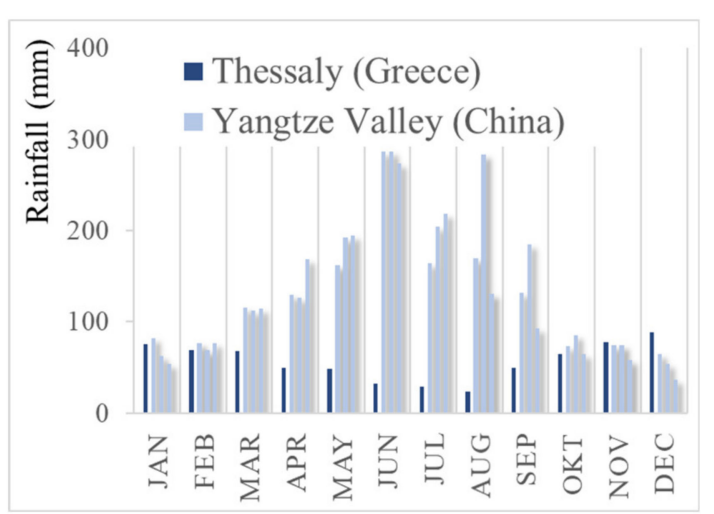

(b)

Figure 16. Climate data of Thessaly (Greece) and different areas in the Yangtze Valley (China). (a) Temperature; (b) Rainfall [119].

Two types of analyses were conducted. The first involved the comparison of the three alternatives on a unit area basis (per hectare). The main outcomes are summarized in Table 2. Since the total energy consumption per capita in Greece for domestic uses is about 110 GJ [108], one hectare of PV panels can fulfill the energy needs of 19 people. On the other hand, the daily food caloric supply per capita in Greece is about 3350 (5.2 GJ annually). Under the hypothetical context that people fulfill their food needs exclusively by wheat or kiwifruit, we conclude that one hectare of cultivated land equals the caloric needs of 10-19 and 20 people, respectively (annually needs $~ 912,500 \mathrm{kcal}$ ). We remark that while kiwifruit is more efficient from a market point-of-view (one ha can produce up to $40 \mathrm{t}$, in contrast to wheat that produces only $4-7 \mathrm{t}$ ), it needs much more water for irrigation.

Table 2. PV panel, cultivation of wheat and kiwifruit (annually quantities in Thessaly per ha).

\begin{tabular}{|c|c|c|c|c|}
\hline & & Consumption & Production & Conversion of Annual Needs \\
\hline \multirow{4}{*}{ PV panels } & Energy & $151 \mathrm{GJ} *$ & $2255 \mathrm{GJ}$ & \multirow{4}{*}{$\begin{array}{l}\text { energy needs of } 19 \text { people; } \\
\text { average in Greece }\end{array}$} \\
\hline & Water & $* *$ & & \\
\hline & Food & & & \\
\hline & Energy & 19.5 GJ [120] & $55.4-97 \mathrm{GJ} * * *$ & \\
\hline \multirow[t]{3}{*}{ Wheat } & Water & $0-1500 \mathrm{~m}^{3}[121]$ & & \multirow[t]{3}{*}{ 10-19 (people; food) } \\
\hline & Food & & $4-7 \mathrm{t}$ & \\
\hline & Energy & 30.5 GJ [122] & $100.48 \mathrm{MJ} * * * *$ & \\
\hline \multirow[t]{2}{*}{ Kiwifruit } & Water & $\begin{array}{c}7000-8000 \mathrm{~m}^{3} \\
{[118]}\end{array}$ & & \multirow[t]{2}{*}{20 (people; food) } \\
\hline & Food & - & $40 \mathrm{t}$ & \\
\hline
\end{tabular}

${ }^{*}$ Embodied energy of panels [123], apported in 20 years of use; ${ }^{* *}$ Hidden water must be in the consumption of the construction of PV panels which cannot be estimated; ${ }^{* * *} 1 \mathrm{~kg}$ wheat $=3310$ kilocalories [124]; ${ }^{* * * *} 1 \mathrm{~kg}$ kiwifruit $=610$ kilocalories [125]. 
The second analysis involved the development of a real-world PV park in Central Thessaly, that extends over an area of 1.3 ha [102]. The total power capacity of the plant is $500 \mathrm{~kW}$. For the estimation of mean annual energy production, we considered the typical value of $1485 \mathrm{kWh} / \mathrm{kWp}$, increased by $15 \%$ under the assumption of applying a solar module tracking system. Taking an investment period of 20 years, a financial analysis was employed [115] and contrasted to the development of the two alternative food sources, i.e., kiwifruit and wheat. Figure 17 illustrates the financial flows for:

- Solar parks, based on recent (2021) prices of electricity produced by PV parks;

- Financial needs and aspects of the cultivation of kiwifruit in 2021 prices;

- Financial needs and aspects of the cultivation of wheat in 2021 prices.

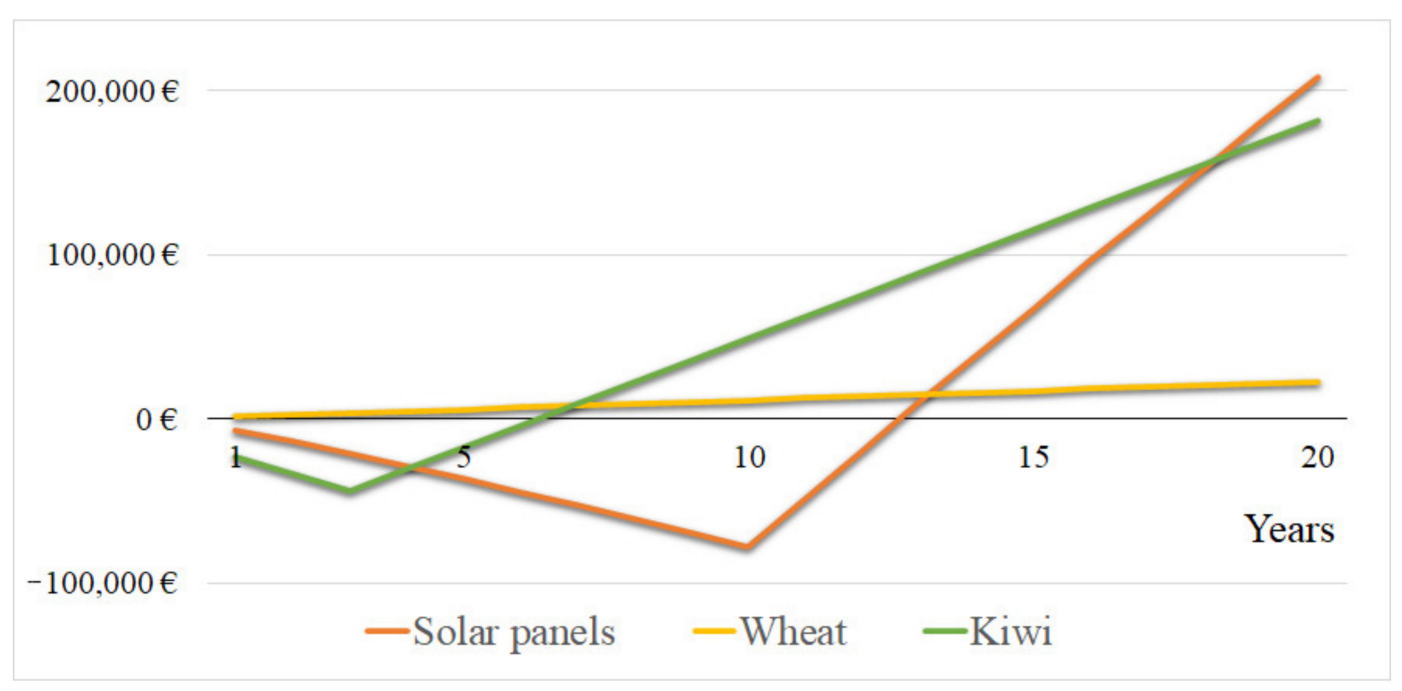

Figure 17. Cumulative financial outflows and inflows for different activities [115].

The above analysis indicates that an investment in kiwifruit is highly efficient (almost the same with PV panels), and needs less than half of the investment for PV panels. The time needed for the depreciation of the investment cost for kiwifruit crops is about 7 years, while for PV panels it is around 12 years.

Under an extreme scenario of agricultural development based on kiwifruit over the entire area of Thessaly, the total water needs will reach $3000 \mathrm{hm}^{3}$, while the available surface water resources are only $340 \mathrm{hm}^{3}$ [94] (Figure 18). Obviously, this a non-sustainable option, given that the groundwater resources of Thessaly are under substantial stress.

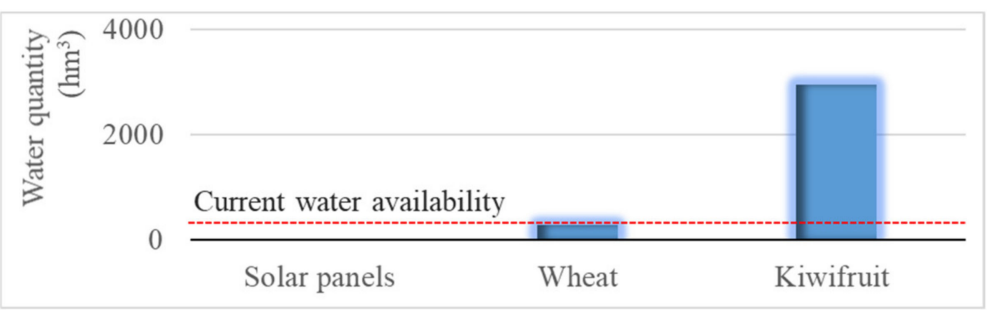

Figure 18. Water needs for Thessaly plain if there was only wheat or kiwifruit.

Finally, in Figure 19, we plot the energy balance of the three alternatives, on a life-cycle basis. In terms of pure production, the PV development is by far more beneficial. 


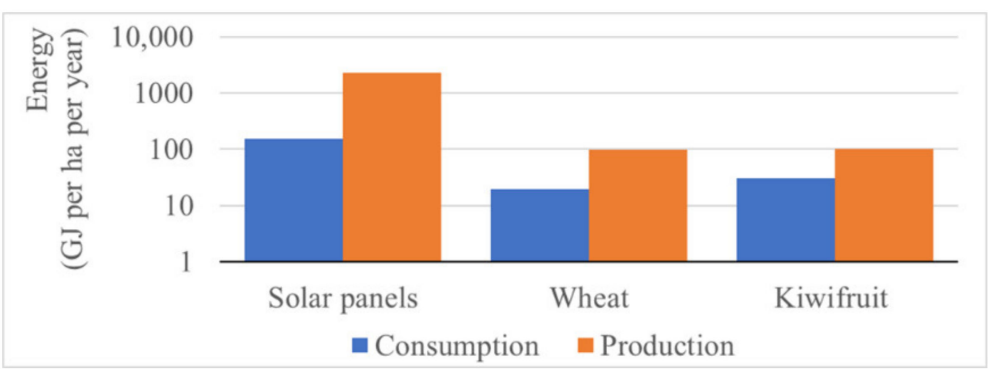

Figure 19. Annual energy needs and energy production per ha (energy by food is converted from calories to Joule).

\section{Conclusions}

The WEF nexus is very crucial to human survival, economy, and sustainable development, as the supply and consumption of each of the three elements is top priority. As demand grows, there is increasing competition among water, energy, agriculture (food), and other sectors with unpredictable impacts for livelihoods and the environment. The study of the WEF nexus may lead to beneficial changes to the ways that we produce and consume. However, these fundamental elements across the WEF systems are highly interconnected with a complex and strongly non-linear relationship and the research of their synergies and conflicts is very important. It is interesting that the scientific community focused on it just in the last decade.

Here, we implemented a comparative analysis of PV development vs. agricultural activity in the main agricultural region in Greece, Thessaly. In particular, we investigated three possible scenarios: (a) the development of solar infrastructures without agricultural use of land, (b) land usage exclusively for wheat cultivation, and (c) land usage exclusively for kiwifruit cultivation. Although the kiwifruit production gives a much higher economic gain than the wheat cultivation, producing almost equivalent results with wheat in term of calories, the water demands are too high, making this option unsustainable. On the other hand, the installation of PV panels, from an economic perspective, is more cost effective than the other two land use options.

Initially, the development of PV parks requires a large investment fund, if compared with the other two options, but in its life cycle, the revenue of energy production and the negligible water demand highlight this scenario as the best solution for our case study. Nonetheless, whereas energy is essential for prosperity, it is not edible, thus food security is first priority.

Moreover, we observed that successful cultivation paradigms (such as kiwifruit production) and ideas which are not adjusted to the local characteristics of the area could be very harmful and very unsustainable.

The problem described in this article can serve as a framework for future actions for sustainable development within the water-energy-food-land nexus. This will require extending the research to other areas, with varying hydroclimatic and socioeconomic characteristics, and accounting for various types of crops. This will allow extracting more generic conclusions with respect to the conflicts and synergies between all elements of the nexus.

Author Contributions: Conceptualization, D.K. and G.-F.S.; methodology, P.S. and G.-F.S.; validation, G.-F.S. and A.E.; formal analysis, G.-F.S. and P.S.; investigation, D.K., G.-F.S., and P.S.; data curation, G.-F.S. and P.S.; writing — original draft preparation, G.-F.S., D.K., and A.E.; writing—review and editing, G.-K.S. and M.C.; visualization, G.-F.S.; supervision, D.K.; project administration, G.-F.S. All authors have read and agreed to the published version of the manuscript.

Funding: This research received no external funding.

Institutional Review Board Statement: Not applicable.

Informed Consent Statement: Not applicable. 
Data Availability Statement: The databases that have been used are referred to in detail in the citation given in the text and are publicly available. In addition, we have used data from: Google Books, Ngram Viewer, available online: https:/ /books.google.com/ngrams (accessed on 27 June 2021) and Scopus, available online: https:/ / www.scopus.com/ (accessed on 27 June 2021).

Acknowledgments: We thank the editors of Sustainability-MDPI for the invitation to contribute with a paper and the processing of the paper, as well as four anonymous reviewers for comments that helped improve and enrich the manuscript.

Conflicts of Interest: The authors declare no conflict of interest.

\section{References}

1. Sargentis, G.-F.; Iliopoulou, T.; Dimitriadis, P.; Mamassis, N.; Koutsoyiannis, D. Stratification: An Entropic View of Society's Structure. World 2021, 2, 11. [CrossRef]

2. Pimentel, D.; Pimentel, M. World Population, Food, Natural Resources, and Survival. World Futures 2003, 59, 145-167. [CrossRef]

3. Gulati, M.; Jacobs, I.; Jooste, A.; Naidoo, D.; Fakir, S. The Water-energy-food Security Nexus: Challenges and Opportunities for Food Security in South Africa. Aquat. Procedia 2013, 1, 150-164. [CrossRef]

4. Simpson, G.B.; Badenhorst, J.; Jewitt, G.; Berchner, M.; Davies, E. Competition for Land: The Water-Energy-Food Nexus and Coal Mining in Mpumalanga Province, South Africa. Front. Environ. Sci. 2019, 7, 86. [CrossRef]

5. Yu, L.; Xiao, Y.; Zeng, X.; Li, Y.; Fan, Y. Planning water-energy-food nexus system management under multi-level and uncertainty. J. Clean. Prod. 2020, 251, 119658. [CrossRef]

6. Del Borghi, A.; Moreschi, L.; Gallo, M. Circular economy approach to reduce water-energy-food nexus. Curr. Opin. Environ. Sci. Health 2020, 13, 23-28. [CrossRef]

7. Food and Agriculture Organization of United Nations. The Water-Energy-Food Nexus A New Approach in Support of Food Security and Sustainable Agriculture. Rome. 2014. Available online: http://www.fao.org/3/bl496e/bl496e.pdf (accessed on 28 June 2021).

8. Rulli, M.C.; Bellomi, D.; Cazzoli, A.; De Carolis, G.; D'Odorico, P. The water-land-food nexus of first-generation biofuels. Sci. Rep. 2016, 6, 22521. [CrossRef]

9. Magliocca, N.R. Agent-Based Modeling for Integrating Human Behavior into the Food-Energy-Water Nexus. Land 2020, 9, 519. [CrossRef]

10. Berndes, G.; Cowie, A.L.; Dale, V.H.; Kline, K.L.; Johnson, F.X.; Langeveld, H.; Sharma, N.; Watson, H.; Woods, J. Energy and Land Use; United Nations Convention to Compact Desertification (UNCCD) and International Renewable Energy Agency (IRENA), 2017. Available online: http://iinas.org/tl_files/iinas/downloads/land/IINAS_2017_UNCCD-IRENA_Energy-Land_paper.pdf (accessed on 27 June 2021).

11. Food and Agriculture Organization of the United Nations. BIOFUELS: Prospects, Risks and Opportunities; Food and Agriculture Organization of the United Nations: Rome, Italy, 2008; Available online: http:/ /www.fao.org/3/i0100e/i0100e00.htm (accessed on 27 June 2021).

12. Popp, J.; Lakner, Z.; Harangi-Rákos, M.; Fári, M. The effect of bioenergy expansion: Food, energy, and environment. Renew. Sustain. Energy Rev. 2014, 32, 559-578. [CrossRef]

13. Stenzel, F.; Greve, P.; Lucht, W.; Tramberend, S.; Wada, Y.; Gerten, D. Irrigation of biomass plantations may globally increase water stress more than climate change. Nat. Commun. 2021, 12, 1-9. [CrossRef] [PubMed]

14. Marta, A.D.; Natali, F.; Mancini, M.; Ferrise, R.; Bindi, M.; Orlandini, S. Energy and Water Use Related to the Cultivation of Energy Crops: A Case Study in the Tuscany Region. Ecol. Soc. 2011, 16. [CrossRef]

15. Teter, J.; Yeh, S.; Khanna, M.; Berndes, G. Water impacts of U.S. biofuels: Insights from an assessment combining economic and biophysical models. PLoS ONE 2018, 13, e0204298. [CrossRef]

16. OECD. The Land-Water-Energy Nexus; OECD Publishing: Paris, France, 2017.

17. Hoff, H. Managing the Water-Land-Energy Nexus for Sustainable Development. United Nations Chronicle. Available online: https://www.un.org/en/chronicle/article/managing-water-land-energy-nexus-sustainable-development (accessed on 29 June 2021).

18. Spang, E.S.; Moomaw, W.; Gallagher, K.S.; Kirshen, P.; Marks, D.H. The water consumption of energy production: An international comparison. Environ. Res. Lett. 2014, 9, 105002. [CrossRef]

19. Koutsoyiannis, D. Revisiting the global hydrological cycle: Is it intensifying? Hydrol. Earth Syst. Sci. 2020, 24, 3899-3932. [CrossRef]

20. Trenberth, K.E.; Fasullo, J.; Kiehl, J. Earth's Global Energy Budget. Bull. Am. Meteorol. Soc. 2009, 90, 311-324. [CrossRef]

21. Mamassis, N.; Efstratiadis, A.; Dimitriadis, P.; Iliopoulou, T.; Ioannidis, R.; Koutsoyiannis, D. Water and Energy. In Handbook of Water Resources Management: Discourses, Concepts and Examples; Bogardi, J.J., Tingsanchali, T., Nandalal, K.D.W., Gupta, J., Salamé, L., van Nooijen, R.R.P., Kolechkina, A.G., Kumar, N., Bhaduri, A., Eds.; Springer Nature: Cham, Switzerland, 2021; Chapter 20; pp. 617-655. [CrossRef]

22. Franck, S.; Von Bloh, W.; Müller, C.; Bondeau, A.; Sakschewski, B. Harvesting the sun: New estimations of the maximum population of planet Earth. Ecol. Model. 2011, 222, 2019-2026. [CrossRef] 
23. Lewis, F.J. Photosynthesis and Related Processes. Nat. Cell Biol. 1945, 156, 487-488. [CrossRef]

24. Kvenvolden, K.A. Organic geochemistry-A retrospective of its first 70 years. Org. Geochem. 2006, 37, 1-11. [CrossRef]

25. McMahon, J.E.; Price, S.K. Water and Energy Interactions. Annu. Rev. Environ. Resour. 2011, 36, 163-191. [CrossRef]

26. IRENA. Renewable Energy in the Water, Energy \& Food Nexus. 2015. Available online: https://www.irena.org/-/media/Files/ IRENA/Agency/Publication/2015/IRENA_Water_Energy_Food_Nexus_2015.pdf (accessed on 27 June 2021).

27. Rehman, S.; Al-Hadhrami, L.M.; Alam, M. Pumped hydro energy storage system: A technological review. Renew. Sustain. Energy Rev. 2015, 44, 586-598. [CrossRef]

28. Castillo, R.M.; Feng, K.; Hubacek, K.; Sun, L.; Guilhoto, J.; Miralles-Wilhelm, F. Uncovering the Green, Blue, and Grey Water Footprint and Virtual Water of Biofuel Production in Brazil: A Nexus Perspective. Sustainability 2017, 9, 2049. [CrossRef]

29. Gerbens-Leenes, P.; van Lienden, A.; Hoekstra, A.; van der Meer, T. Biofuel scenarios in a water perspective: The global blue and green water footprint of road transport in 2030. Glob. Environ. Chang. 2012, 22, 764-775. [CrossRef]

30. Gerbens-Leenes, W.; Hoekstra, A.; van der Meer, T.H. The water footprint of bioenergy. Proc. Natl. Acad. Sci. USA 2009, 106, 10219-10223. [CrossRef] [PubMed]

31. Water Implications of Biofuels Production in the U.S; Report in Brief; The National Academies, October 2007. Available online: https:/ / www.nap.edu/resource/12039/biofuels_brief_final.pdf (accessed on 27 June 2021).

32. Geoff, K.; Jackson, S.; Napoleon, A.; Comings, T.; Ramey, J.A. The Hidden Costs of Electricity: Comparing the Hidden Costs of Power Generation Fuels; Civil Society Institute: Cambridge, UK, 19 September 2009. Available online: https:/ / www.synapse-energy. com/sites/default/files/SynapseReport.2012-09.CSI_.Hidden-Costs.12-013.pdf (accessed on 27 June 2021).

33. Yergin, D.; Frei, C. Energy Vision Update 2009. Thirsty Energy: Water and Energy in the 21st Century; World Economic Forum/Cambridge Energy Research Association: Geneva, Switzerland, 2009.

34. Davis, L. Body Physics: Motion to Metabolism, Open Oregon Educational Resources. EBOOK ISBN 978-1-63635-046-2. Available online: https:/ / openoregon.pressbooks.pub/bodyphysics/ (accessed on 5 April 2021).

35. Bryce, E. How Many Calories Can the Brain Burn by Thinking? 9 November 2019. Available online: https://www.livescience. com/burn-calories-brain.html (accessed on 27 June 2021).

36. United Nations University; World Health Organization. Human Energy Requirements: Report of a Joint FAO/WHO/UNU Expert Consultation; Food \& Agriculture Org: Rome, Italy, October 2001; Volume 1, pp. 17-24. Available online: http://www.fao.org/3/ y5686e/y5686e.pdf (accessed on 29 June 2021).

37. UNICEF. Water, Sanitation and Hygiene. United Nations International Children's Emergency Fund (UNICEF). Available online: www.unicef.org/wash (accessed on 27 June 2021).

38. World Bank. Water in Agriculture. Available online: https://www.worldbank.org/en/topic/water-in-agriculture (accessed on 27 June 2021).

39. Share of Freshwater Withdrawals Used in Industry. Available online: https://ourworldindata.org/water-use-stress (accessed on 27 June 2021).

40. Sargentis, G.-F.; Dimitriadis, P.; Ioannidis, R.; Iliopoulou, T.; Frangedaki, E.; Koutsoyiannis, D. Optimal utilization of water resources for local communities in mainland Greece (case study of Karyes, Peloponnese). Procedia Manuf. 2020, 44, 253-260, ISSN 2351-9789. [CrossRef]

41. Sargentis, G.-F.; Ioannidis, R.; Karakatsanis, G.; Sigourou, S.; Lagaros, N.D.; Koutsoyiannis, D. The Development of the Athens Water Supply System and Inferences for Optimizing the Scale of Water Infrastructures. Sustainability 2019, 11, 2657. [CrossRef]

42. Hadjibiros, K.; Katsiri, A.; Andreadakis, A.; Koutsoyiannis, D.; Stamou, A.; Christofides, A.; Efstratiadis, A.; Sargentis, G.-F. Multi-criteria reservoir water management. Glob. NEST J. 2005, 7, 386-394. [CrossRef]

43. Alcamo, J.; Döll, P.; Henrichs, T.; Kaspar, F.; Lehner, B.; Rösch, T.; Siebert, S. Development and testing of the WaterGAP 2 global model of water use and availability. Hydrol. Sci. J. 2003, 48, 317-337. [CrossRef]

44. Aus der Beek, T.; Flörke, M.; Lapola, D.M.; Schaldach, R.; Voß, F.; Teichert, E. Modelling historical and current irrigation water demand on the continental scale: Europe. Adv. Geosci. 2010, 27, 79-85. [CrossRef]

45. United Nations. 2019 Revision of World Population Prospects. Available online: https://population.un.org/wpp/ (accessed on 27 June 2021).

46. Global Population. Available online: https:/ / clio-infra.eu/Indicators/TotalPopulation.html (accessed on 27 June 2021).

47. Life Expectancy. Available online: https:// ourworldindata.org/life-expectancy (accessed on 5 October 2020).

48. UNU. World Income Inequality Database-WIID. Available online: https://www.wider.unu.edu/database/wiidhttps://www. wider.unu.edu/database/wiid (accessed on 27 June 2021).

49. Ostwald, W. Energetische Grundlagen der Kulturwissenschaft; Klinkhardt: Germany, Leipzig, 1909.

50. Hoff, H. Understanding the Nexus. Background Paper for the Bonn 2011 Nexus Conference: The Water, Energy and Food Security; Nexus: Bonn, Germany. 2011; Available online: https://www.sei.org/publications/understanding-the-nexus/ (accessed on 27 June 2021).

51. BP. Statistical Review of World Energy. Available online: https://www.bp.com/en/global/corporate/energy-economics/ statistical-review-of-world-energy.html (accessed on 27 June 2021).

52. Maddison Project Database 2018. Available online: https://www.rug.nl/ggdc/historicaldevelopment/maddison/releases/ maddison-project-database-2018 (accessed on 27 June 2021). 
53. Gustavsson, J.; Cederberg, C.; Sonesson, U.; Van Otterdijk, R.; Meybeck, A. Global Food Losses and Food Waste; Food and Agriculture Organization of the United Nations: Düsseldorf, Germany, 2011.

54. Prosekov, A.Y.; Ivanova, S.A. Food security: The challenge of the present. Geoforum 2018, 91, 73-77. [CrossRef]

55. FAO; IFAD; UNICEF; WFP; WHO. The State of Food Security and Nutrition in the World 2020. Transforming Food Systems for Affordable Healthy Diets; FAO: Rome, Italy, 2020. [CrossRef]

56. Mercy Corps. The Facts: What You Need to Know about Global Hunger. Available online: https://www.mercycorps.org/blog/ quick-facts-global-hunger (accessed on 27 June 2021).

57. FAOSTAT. United Nations Food and Agricultural Organization (FAO). Available online: http://www.fao.org/faostat/en/\#data/ FBS (accessed on 27 June 2021).

58. Bank of England. Home Statistics Research Datasets. Available online: https://www.bankofengland.co.uk/statistics/researchdatasets (accessed on 27 June 2021).

59. Koutsoyiannis, D.; Makropoulos, C.; Langousis, A.; Baki, S.; Efstratiadis, A.; Christofides, A.; Karavokiros, G.; Mamassis, N. Climate, hydrology, energy, water: Recognizing uncertainty and seeking sustainability. Hydrol. Earth Syst. Sci. 2009, 13, 247-257. [CrossRef]

60. Simpson, G.B.; Graham, J. The Development of the Water-Energy-Food Nexus as a Framework for Achieving Resource Security: A Review. Front. Environ. Sci. V. 2019, 7, 8. [CrossRef]

61. WEF (World Economic Forum). Global Risks 2011, Sixth Edition: An Initiative of the Risk Response Network. 2011. Available online: http:/ / reports.weforum.org/global-risks-2011/ (accessed on 27 June 2021).

62. The Water, Energy \& Food Security Resource Platform. Available online: https://www.water-energy-food.org/ (accessed on 27 June 2021).

63. Yang, J.; Yamazaki, A. Water and energy nexus: A literature review. Water West Stanf. Univ 2013, 1, 146. Available online: https:/ / waterinthewest.stanford.edu/sites/default/files/Water-Energy_Lit_Review_0.pdf (accessed on 27 June 2021).

64. WEF Nexus Index. Available online: https:/ / wefnexusindex.org/ (accessed on 27 June 2021).

65. Albrecht, T.R.; Crootof, A.; Scott, C. The Water-Energy-Food Nexus: A systematic review of methods for nexus assessment. Enviromental Res. Lett. 2018, 13, 4. [CrossRef]

66. Sargentis, G.-F.; Iliopoulou, T.; Sigourou, S.; Dimitriadis, P.; Koutsoyiannis, D. Evolution of Clustering Quantified by a Stochastic Method-Case Studies on Natural and Human Social Structures. Sustainability 2020, 12, 7972. [CrossRef]

67. Chatzimpiros, P.; Lagos, G.; Sargentis, G.-F. Man and City. Myth and Vision. In Proceedings of the 10th International Conference on Environmental Science and Technology, Kos Island, Greece, 5-7 September 2007; Department of Environmental Studies, University of the Aegean. [CrossRef]

68. WEF Background. Available online: www.water-energy-food.org/mission (accessed on 27 June 2021).

69. IRENA. Global Energy Transformation: A Roadmap to 2050. 2019. Available online: https://www.irena.org/publications/2019 / Apr/Global-energy-transformation-A-roadmap-to-2050-2019Edition (accessed on 27 June 2021).

70. Michael, D.; Sockol, D.; Raichlen, A.; Herman, P. Chimpanzee locomotor energetics and the origin of human bipedalism. Proc. Natl. Acad. Sci. USA 2007, 104, 12265-12269. [CrossRef]

71. Boyer, D.M.; Harrington, A.R. Scaling of bony canals for encephalic vessels in euarchontans: Implications for the role of the vertebral artery and brain metabolism. J. Hum. Evol. 2018, 114, 85-101, ISSN 0047-2484. [CrossRef] [PubMed]

72. Manta, E.; Ioannidis, R.; Sargentis, G.-F.; Efstratiadis, A. Aesthetic evaluation of wind turbines in stochastic setting: Case study of Tinos island, Greece. In Proceedings of the European Geosciences Union General Assembly 2020, Online. 4-8 May 2020; European Geosciences Union Geophysical Research Abstracts. ; Volume 22. EGU2020-5484. [CrossRef]

73. Ioannidis, R.; Dimitriadis, P.; Meletopoulos, I.T.; Sargentis, G.-F.; Koutsoyiannis, D. Investigating the spatial characteristics of GIS visibility analyses and their correlation to visual impact perception with stochastic tools. In Proceedings of the European Geosciences Union General Assembly, Online. 4-8 May 2020; European Geosciences Union Geophysical Research Abstracts. ; Volume 22. EGU2020-18212. [CrossRef]

74. Ioannidis, R.; Dimitriadis, P.; Sargentis, G.-F.; Frangedaki, E.; Iliopoulou, T.; Koutsoyiannis, D. Stochastic similarities between hydrometeorogical and art processes for optimizing architecture and landscape aesthetic parameters. In Proceedings of the European Geosciences Union General Assembly 2019, Vienna, Austria, 7-12 April 2019; European Geosciences Union Geophysical Research Abstracts. , 2019; Volume 21. EGU2019-11403. Available online: https://www.itia.ntua.gr/en/docinfo/1946/ (accessed on 27 June 2021).

75. Ioannidis, R.; Koutsoyiannis, D. A review of land use, visibility and public perception of renewable energy in the context of landscape impact. Appl. Energy 2020, 276, 115367. [CrossRef]

76. IRENA. Renewable Capacity Statistics 2021; International Renewable Energy Agency (IRENA): Abu Dhabi, United Arab Emirates, 2021; ISBN 978-92-9260-342-7.

77. Mamassis, N.; Efstratiadis, A.; Apostolidou, E. Topography-adjusted solar radiation indices and their importance in hydrology. Hydrol. Sci. J. 2012, 57, 756-775. [CrossRef]

78. Adeh, E.H.; Good, S.P.; Calaf, M.; Higgins, C.W. Solar PV Power Potential is Greatest Over Croplands. Sci. Rep. 2019, 9. [CrossRef] [PubMed]

79. Späth, L. Large-scale photovoltaics? Yes please, but not like this! Insights on different perspectives underlying the trade-off between land use and renewable electricity development. Energy Policy 2018, 122, 429-437. [CrossRef] 
80. Guerin, T.F. Impacts and opportunities from large-scale solar photovoltaic (PV) electricity generation on agricultural production. Environ. Qual. Manag. 2019. [CrossRef]

81. Dias, L.; Gouveia, J.P.; Lourenço, P.; Seixas, J. Interplay between the potential of photovoltaic systems and agricultural land use. Land Use Policy 2019, 81, 725-735. [CrossRef]

82. Nonhebel, S. Renewable energy and food supply: Will there be enough land? Renew. Sustain. Energy Rev. 2005, 9, 191-201. [CrossRef]

83. Sacchelli, S.; Garegnani, G.; Geri, F.; Grilli, G.; Paletto, A.; Zambelli, P.; Ciolli, M.; Vettorato, D. Trade-off between photovoltaic systems installation and agricultural practices on arable lands: An environmental and socio-economic impact analysis for Italy. Land Use Policy 2016, 56, 90-99. [CrossRef]

84. Sargentis, G.-F.; Dimitriadis, P.; Ioannidis, R.; Iliopoulou, T.; Koutsoyiannis, D. Stochastic Evaluation of Landscapes Transformed by Renewable Energy Installations and Civil Works. Energies 2019, 12, 2817. [CrossRef]

85. Sargentis, G.-F.; Ioannidis, R.; Chiotinis, M.; Dimitriadis, P.G.; Koutsoyiannis, D. Aesthetical Issues with Stochastic Evaluation. In Data Analytics for Cultural Heritage; Belhi, A., Bouras, A., Al-Ali, A.K., Sadka, A.H., Eds.; Springer Science and Business Media LLC: New York, NY, USA, 2021; pp. 173-193.

86. Delfanti, L.; Colantoni, A.; Recanatesi, F.; Bencardino, M.; Sateriano, A.; Zambon, I.; Salvati, L. Solar plants, environmental degradation and local socioeconomic contexts: A case study in a Mediterranean country. Environ. Impact Assess. Rev. 2016, 61, 88-93. [CrossRef]

87. Dinesh, H.; Pearce, J.M. The potential of agrivoltaic systems. Renew. Sustain. Energy Rev. 2016, 54, 299-308. [CrossRef]

88. Dupraz, C.; Marrou, H.; Talbot, G.; Dufour, L.; Nogier, A.; Ferard, Y. Combining solar photovoltaic panels and food crops for optimising land use: Towards new agrivoltaic schemes. Renew. Energy 2011, 36, 2725-2732. [CrossRef]

89. Pascaris, A.S.; Schelly, C.; Burnham, L.; Pearce, J.M. Integrating solar energy with agriculture: Industry perspectives on the market, community, and socio-political dimensions of agrivoltaics. Energy Res. Soc. Sci. 2021, 75, 102023. [CrossRef]

90. Weselek, A.; Ehmann, A.; Zikeli, S.; Lewandowski, I.; Schindele, S.; Högy, P. Agrophotovoltaic systems: Applications, challenges, and opportunities. A review. Agron. Sustain. Dev. 2019, 39, 35. [CrossRef]

91. Hellenic Statistical Authority, Agriculture and Livestock. Available online: https://www.statistics.gr/el/statistics/agr/(accessed on 27 June 2021).

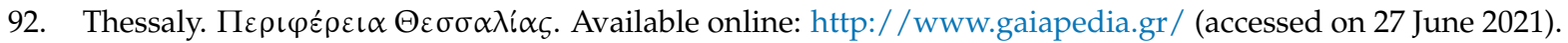

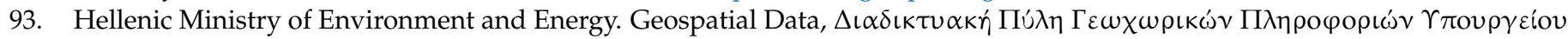

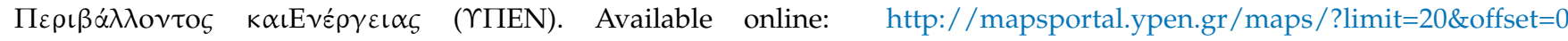
(accessed on 27 June 2021).

94. Koutsogiannis, D.; Andreadakis, A.; Mavrodimou, R.; Christofidis, A.; Mamasis, N.; Efstratiadis, A.; Koukouvinos, A.; Karavokyros, G.; Kozanis, S.; Mamais, D.; et al. National Management and Protection Program of Water Resources, Support for the Preparation of National Program for Management and Protection of Water Resources; Department of Water Resources and Environment-National Technical University of Athens: Athens, Greece, 2008; 748p. [CrossRef]

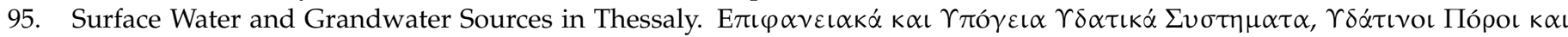

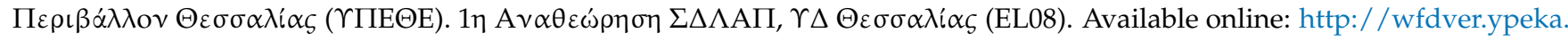
gr/wp-content/uploads/2017/12/EL08_SDLAP_APPROVED.pdf (accessed on 27 June 2021).

96. Smith, A. Ancient and Traditional Agriculture, Pastoralism, and Agricultural Societies in Sub-Saharan Africa. Oxf. Res. Encycl. Environ. Sci. 2019. [CrossRef]

97. Jiang, Y.; Zhang, Q.; Niu, J.; Wu, J. Pastoral Population Growth and Land Use Policy Has Significantly Impacted Livestock Structure in Inner Mongolia-A Case Study in the Xilinhot Region. Sustainability 2019, 11, 7208. [CrossRef]

98. Davis, J.; Hatfield, R. The economics of mobile pastoralism: A global summary. Nomadic Peoples 2007, 11, 91-116. Available online: www.jstor.org/stable/43123794 (accessed on 12 December 2020). [CrossRef]

99. Coughenour, M.B.; Ellis, J.E.; Swift, D.M.; Coppock, D.L.; Galvin, K.; McCabe, J.T.; Hart, T.C. Energy extraction and use in a nomadic pastoral ecosystem. Science 1985, 230, 619-625. [CrossRef]

100. Smil, V. Conversion of Energy: People and Animals. In Encyclopedia of Energy; Cutler, J., Ed.; Elsevier: Amsterdam, The Netherlands, 2004; pp. 697-705. ISBN 9780121764807. [CrossRef]

101. Smil, V. World History and Energy. In Encyclopedia of Energy; Cutler, J., Ed.; Elsevier: Amsterdam, The Netherlands, 2004; pp. 549-561. ISBN 9780121764807. [CrossRef]

102. Singh, H.; Mishra, D.; Nahar, N.M. Energy use pattern in production agriculture of a typical village in arid zone, India. Energy Convers. Manag. 2002, 43, 2275-2286, ISSN 0196-8904. [CrossRef]

103. Canakci, M.; Topakci, M.; Akinci, I.; Ozmerzi, A. Energy use pattern of some field crops and vegetable production: Case study for Antalya Region, Turkey. Energy Convers. Manag. 2005, 46, 655-666, ISSN 0196-8904. [CrossRef]

104. Kander, A.; Warde, P. Energy Availability from Livestock and Agricultural Productivity in Europe, 1815-1913: A New Comparison. Econ. Hist. Rev. 2011, 64, 1-29. Available online: http:/ /www.jstor.org/stable/27919479 (accessed on 27 June 2021). [CrossRef]

105. Schnepf, R. Energy Use in Agriculture: Background and Issues, CRS Report for Congress, Received through the CRS Web. 2004. Available online: https:/ / nationalaglawcenter.org/wp-content/uploads/assets/crs/RL32677.pdf (accessed on 27 June 2021). 
106. Vreni, J.-R.; Crump, L.; Abicho, A.A.; Abakar, A.A.; Mahamat, A., II; Bechir, M.; Eckert, S.; Engesser, M.; Schelling, E.; Zinsstag, J. Estimating population and livestock density of mobile pastoralists and sedentary settlements in the south-eastern Lake Chad area. Geospat. Health 2015, 10. [CrossRef]

107. Energy for Agriculture. Available online: http:/ /www.fao.org/3/X8054E/x8054e05.htm (accessed on 27 June 2021).

108. Greece: Energy Country Profile. Available online: https:/ / ourworldindata.org/energy/country/greece (accessed on 27 June 2021 ).

109. Greek Low 2773/1999, (ФEK 286/A/22-12-1999). Available online: https://ypen.gov.gr/wp-content/uploads/2020/11/\%CE\%A6 \%CE\%95\%CE\%9A-\%CE\%91_286_1999.pdf (accessed on 27 June 2021).

110. Directive 96/92/EC of the European Parliament and of the Council of 19 December 1996. Available online: https:/ / eur-lex. europa.eu/legal-content/EN/TXT/?uri=CELEX\%3A31996L0092 (accessed on 27 June 2021).

111. Laboratory of Atmospheric Physics of the University of Patras. Climatological Maps of Sollar Energy in Greece, Greek Network

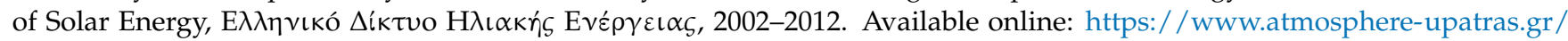
solarmaps/Thessaly (accessed on 27 June 2021).

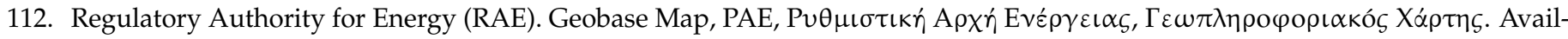
able online: https:/ / geo.rae.gr/ (accessed on 27 June 2021).

113. Greek low 4643/2019 (ФEK 193/A/3-12-2019). Available online: http:/ / www.et.gr/idocs-nph/search/pdfViewerForm.html? args=5C7QrtC22wFqnM3eAbJzrXdtvSoClrL8u_IHzLbdDJF5MXD0LzQTLWPU9yLzB8V68knBzLCmTXKaO6fpVZ6Lx3UnK13 nP8NxdnJ5r9cmWyJWelDvWS_18kAEhATUkJb0x1LIdQ163nV9K--td6SIuVAzU4FN1TikRIIo27KU01ITu702tbfrwe9cmHeaq6 vE (accessed on 27 June 2021).

114. Global Solar Atlas. Available online: https: / globalsolaratlas.info/map?c=39.461644,22.142944,9\&s=39.374867,22.355804\&m=site (accessed on 27 June 2021).

115. Siamparina, P. Water-Food-Energy Nexus and the Comperative Relasionship of Solar Panels with Agriculutre. Case Study

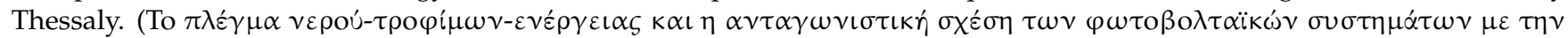

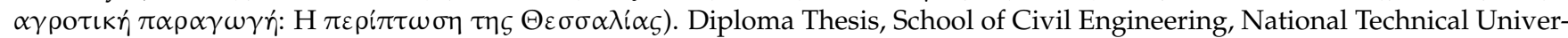
sity of Athens, Athens, Greece, 2021. Available online: https: / www.itia.ntua.gr/el/docinfo/2128/ (accessed on 27 June 2021).

116. Morton, J. Fruints of Warm Climates; Florida Flair Books: Miami, FL, USA, 1987.

117. Holzapfel, E.A.; Merino, R.; Marinno, M.A.; Matta, R. Water production functions in kiwi. Irrig. Sci. 2000, 19, 73-79. Available online: https:/ / link.springer.com/article/10.1007/s002710050003 (accessed on 27 June 2021). [CrossRef]

118. Cultivation of kiwifruit in Greece. Available online: Shorturl.at/doA23 (accessed on 27 June 2021).

119. Climate Data for Cities Worldwide. Available online: https: / / climate-data.org (accessed on 27 June 2021).

120. Visser, C.D.; Buisonjé, F.; Ellen, H.; Stanghellini, C.; Voort, M.V. State of the Art on Energy Efficiency in Agriculture, Country Data on Energy Consumption in Different Agroproduction Sectors in the European Countries. 2012. Available online: https: / / www.semanticscholar.org/paper/State-of-the-Art-on-Energy-Efficiency-in-Country-on-Visser-Buisonj\%C3\%A9 /72f757a4a816fca1bbad065ddb67ff91eac53531 (accessed on 27 June 2021).

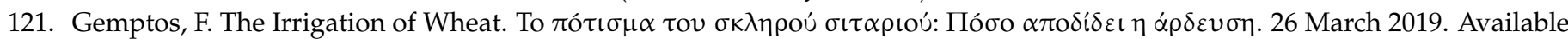
online: https://www.eleftheria.gr/\%CE\%B1\%CE $\%$ B3\%CF $\% 81 \% C E \% B F \% C F \% 84 \% C E \% B 9 \% C E \% B A \% C E \% A C / i t e m / 2264$ $38-\%$ CF $\% 84 \%$ CE $\%$ BF- $\%$ CF $\% 80 \%$ CF $\% 8 C \% C F \% 84 \% C E \% B 9 \% C F \% 83 \% C E \% B C \% C E \% B 1-\% C F \% 84 \% C E \% B F \% C F \% 85-\% C F \% 83$

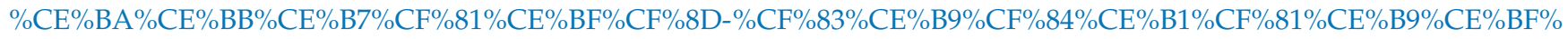
CF\%8D-\%CF\%80\%CF\%8C\%CF\%83\%CE\%BF-\%CE\%B1\%CF\%80\%CE\%BF\%CE\%B4\%CE\%AF\%CE\%B4\%CE\%B5\%CE\%B9-\% CE\%B7-\%CE\%AC\%CF\%81\%CE\%B4\%CE\%B5\%CF\%85\%CF\%83\%CE\%B7.html (accessed on 27 June 2021).

122. Mohammadi, A.; Rafiee, S.; Mohtasebi, S.S.; Rafiee, H. Energy inputs-Yield relationship and cost analysis of kiwifruit production in Iran. Renew. Energy 2010, 35, 1071-1075, ISSN 0960-1481. [CrossRef]

123. Piasecka, I.; Bałdowska-Witos, P.; Piotrowska, K.; Tomporowski, A. Eco-Energetical Life Cycle Assessment of Materials and Components of Photovoltaic Power Plant. Energies 2020, 13, 1385. [CrossRef]

124. Calories 24. Wheat. Available online: https://calories24.com/int/calories-in/wheat (accessed on 27 June 2021).

125. Calories 24. Kiwifruit. Available online: https://calories24.com/int/calories-in/kiwifruit (accessed on 27 June 2021). 